\title{
Land Cover Change and Its Socio-Economic Impact on the Residents of the Mara River, Kenya
}

\author{
Fredrick M. Mngube',2, Douglas N. Anyona², Paul 0. Abuom², Ally-Said Matano1, \\ Raphael A. Kapiyo
}

${ }^{1}$ East Africa-Lake Victoria Basin Commission Secretariat, Kisumu, Kenya

${ }^{2}$ School of Environment and Earth Sciences, Maseno University, Kisumu, Kenya

Email: fredmhina@yahoo.com

How to cite this paper: Mngube, F.M., Anyona, D.N., Abuom, P.O., Matano, A.-S. and Kapiyo, R.A. (2019) Land Cover Change and Its Socio-Economic Impact on the Residents of the Mara River, Kenya. American Journal of Climate Change, 8, 404-438. https://doi.org/10.4236/ajcc.2019.83022

Received: July 6, 2019

Accepted: September 22, 2019

Published: September 25, 2019

Copyright ( 2019 by author(s) and Scientific Research Publishing Inc. This work is licensed under the Creative Commons Attribution International License (CC BY 4.0).

http://creativecommons.org/licenses/by/4.0/

\begin{abstract}
Anthropogenic activities are increasingly catalyzing natural climatic factors that drive land cover change at different spatial scales. Available land cover data of the Mara River basin however give a broader picture of the entire basin regardless of the heterogeneity that exists at the sub-catchment level. This study sought to establish sub-catchment specific information on land cover changes through examination of satellite images of four Mara River sub-catchments (Amala, Nyangores, Talek and Sand River) for the period 1987-2017. The relationship between temperature, rainfall and land cover was also computed. In addition, a household survey and focus group discussions were conducted in each sub-catchments to establish the socio-economic impacts of land cover change on the community's wellbeing. Forest cover was dominant in Amala (39.8\%) and Nyangores (43.7\%) sub-catchments in 1987 but by 2017 crop lands had surpassed forest cover in the two sub-catchments, accounting for $53.2 \%$ and $45.7 \%$, respectively. However, in Talek $(52.8 \%)$ and Sand River (47.4\%) sub-catchments, grassland was the dominant land cover type in 1987 and after the 30 year period, grasslands remained dominant in Sand River, while shrub land became dominant in Talek sub-catchment. A weak positive correlation was observed between rainfall and forest cover, shrub land and cropland, while a negative correlation was observed between rainfall and bare land. Average temperature showed a positive moderate correlation with bare land and built up areas. Analysis of survey data revealed that livestock keeping, temperature increase, type of trees, education level of household head and weak environmental laws were the main drivers of land cover change $(\mathrm{P}<0.05)$, while decline in forest cover, crop failure and shift in planting seasons were attributed to climate change. Pearson correlation of annual precipitation against crop yield for the period 1987-2017 revealed
\end{abstract}


negative correlations for maize $(r=-0.587)$, beans $(r=-0.5459)$, sorghum $(r$ $=-0.351)$, cow peas $(\mathrm{r}=-0.544)$, and pigeon peas $(\mathrm{r}=-0.337)$. Focus group discussions participants were supportive of environmental protective measures to reverse negative land cover changes, while planting drought resistant trees, crop diversification and awareness creation among community members were recommended as the most ideal environmental management strategies.

\section{Keywords}

Land Cover Change, Socio-Economic Impact, Mara River Sub-Catchments, Kenya

\section{Introduction}

Land cover change is regarded as a fundamental component of global environmental change because of its interactions with climates, ecosystems, biodiversity and human beings [1]. Understanding land cover dynamics and its drivers is therefore crucial for resource management and land-use planning [2]. Temperature and rainfall are some of the natural climatic factors that may initiate modifications upon land cover. However, these natural drivers are exacerbated by anthropogenic activities such as agriculture and livestock rearing, forest harvesting, human settlements, and urban development among others [3]. A host of studies have shown the cause-and-effect mechanism between changes in global land cover and climatic factors such as rainfall and temperature [4] [5]. For instance, vegetation removal by overgrazing and firewood collection reduces evaporation potential and may initiate a feedback mechanism that results in lower rainfall and hence affect crop production or induce stunted growth [6]. While several studies have investigated how potential crop yields may be influenced by changes in climate due to anthropogenic greenhouse gas forcing, assessments of the impacts of changing land cover on potential crop yields at major river basins remains scanty.

Globally cropland and pastureland increased five and six fold, respectively, between 1700 and 1990. Over the same period, forest cover decreased significantly, from about 5000 million hectares to 4300 million hectares [7]. Analysis of land cover datasets indicates that pasture land is the most extensive form of land use; accounting for about $22 \%$ - $26 \%$ of the earth's ice-free land surface [8] [9]. While competition for limited land resources has been on the increase across the world, the magnitude of land cover change varies from one region to another [10]. Nonetheless, agriculture is expanding in response to increasing demands for food production, at the expense of natural vegetation and grasslands [11]. As a result, more than one-third of the global land surface is currently devoted to agricultural productivity that has now become one of the largest biomes on the planet [12]

Croplands occupy roughly 15 million $\mathrm{km}^{2}$ of the Earth's surface currently, 
while pasture lands cover approximately 34 million $\mathrm{km}^{2}$. Agriculture has expanded into forests, savannas, and steppes in all parts of the world to meet the ever increasing demand for food and fiber [7]. Therefore, forests and grassland have become the main targets for conversion to agricultural cultivation [13]. Over the past 300 years, $7-11$ million $\mathrm{km}^{2}$ of forest land has been cleared, while about two million $\mathrm{km}^{2}$ of natural forest in temperate and tropical regions are now highly managed plantations with significantly reduced biological diversity [10]. Pressure to increase yields-per-acre has intensified agricultural activities through accelerated use of industrial fertilizers and pesticides, widespread irrigation, introduction of new crop varieties, and mechanization [10] all of which impact on the ecosystem. In addition, land degradation, desertification, biodiversity loss, habitat destruction, water pollution and invasion by alien vegetation species are all consequences of land cover changes that eventually affect human wellbeing [14] [15].

About $40 \%-75 \%$ of the world's arable land's productivity is reduced due to land degradation [16], often with serious consequences on the livelihood of rural communities [17]. Maitima et al. [18] concur that changes in land cover have serious environmental, economical and social impacts on rural livelihoods in many parts of the world; more-so in developing countries. The severity of the impact is aggravated by the high dependency on natural resources, high poverty levels and variability in climate; given that most of their livelihood activities are natural climate dependent [19]. An estimated 300 million people depend on natural forests directly and indirectly [20] and any form of degradation of this critical resource puts to risk their livelihoods.

Agro-pastoral livestock farming system dependent on natural resources is practiced by many rural populations including those in the Mara River basin. For this critical mass, livestock is not only regarded as economic asset and social identity, but also represent socio-cultural and spiritual asset. Therefore diminishing pasture land triggered by land cover change may put such communities under risk of losing their herd especially during prolonged dry periods. Significant changes in land cover can also influence ground and surface water resources on which human beings, livestock and wildlife depend [21]. Water yield is altered through changes in transpiration, interception, infiltration and evaporation processes; which tend to be caused by land cover change. Although studies that relate small scale $\left(<1 \mathrm{~km}^{2}\right)$ changes in land cover to variation in river discharge generally indicate that deforestation causes an increase in the annual mean discharge, those that evaluated the same in large-scale river basins $(>100$ $\mathrm{km}^{2}$ ) did not find similar relationships [22]. This necessitated a study focused on the sub-catchments to ascertain the effect of land cover change on water resources at the local level.

With regard to human health, infectious diseases that are transmitted by vectors or those with non-human hosts or reservoirs are particularly sensitive to land cover changes [23]. Alteration of the biophysical conditions of vector habitats, changing exposure pathways, changing the pathogen's genetic material, al- 
teration of pathogen and vector's life cycles and alteration of species composition within a community of organisms [24] are some of the ways through which land cover change can alter exposure to infectious diseases [25]. Malaria exposure was reported to have increased with rate of deforestation in the Amazon, in South America [26], while the biting rates of $A$. darlingi in deforested areas of Peruvian Amazon were 278 times higher than biting rates in forested areas [27]. A number of studies have also reported associations between deforestation and increased cases of onchocerciasis, yellow fever and cutaneous leishmaniasis in Latin America and increased malaria exposure in sub-Sahara Africa [28] [29] [30]. More detailed studies are however needed to ascertain the full impacts of land cover change on vector-borne diseases especially at the river basin sub-catchment level.

While overwhelming evidence points to a changing climate with corresponding changes in land cover across the world over, different regions are being impacted differently by virtue of their unique and varied characteristics. In the highlands of East Africa for instance, the urge to produce more has pushed farmers to intensify agricultural practices and expand their farms into previously uncultivated land all in a bid to increase their yields [31]. As a result, the area under cultivation has more than doubled over the last few decades [31]. Likewise, Kenya's landscape is continuously changing under the influence of demographic trends, climate variability, national policies, and microeconomic activities. Over the last two decades, land cover change in a number of water towers across the country has adversely affected communities' wellbeing by impacting on a number of livelihood sources.

Like many major water catchments, the Mara River Basin, has witnessed gradual changes in land cover as a result of increased anthropogenic activities coupled with a changing climate. Currently, the Mara River Basin embodies many of the current challenges in biodiversity conservation. It is predicted that if the changes continue at the current rate, then the Mara River may cease to flow completely during dry years [32]. This may cause untold suffering to the wildlife, livestock and communities living within the Mara River Basin. Expanding human settlements, commercial farming activities, tourism and other anthropogenic activities adjacent to the Maasai Mara National Reserve are already causing shortages in water resources; threatening peaceful coexistence of community members and wildlife [33]. However, despite these challenges, little is known about the impacts of land cover changes as a function of rural livelihood strategies in the Mara River sub-catchments. This study thus sought to establish the drivers of land cover change and their resultant socio-economic effects on livelihoods of community members residing within Amala, Nyangores, Sand and Talek sub-catchments of Mara River in Kenya.

\section{Materials and Methods}

\subsection{Study Area Description}

The Mara River Basin is a transboundary watershed that covers an area of 13,750 
$\mathrm{km}^{2}$ and is shared between Kenya (65\%) and Tanzania (35\%) [34]. This study focused on four major sub-catchments (Amala, Nyangores, Talek and Sand River) within the Kenyan part of the Mara River Basin from which the river originates-initially as the Amala and Nyangores tributaries before converging to form the Mara River [34]. The Talek and Sand tributaries join the Mara River in the middle and lower parts of the Kenya side of the Mara River basin before flowing down into Tanzania (Figure 1).

While all the four Mara River tributaries have a dendritic drainage pattern, they are inhomogeneous and therefore exhibit different flow and basin characteristics as well as spatial and temporal arrangements. Amala and Nyangores are perennial, while Talek and Sand tributaries are seasonal. In addition, Amala sub-catchment has less forest cover and is characterized more by crop land and human settlements compared to Nyangores sub-catchment, while Talek and Sand River sub-catchments are characterized by scattered woodlands and extensive grasslands. While Amala and Nyangores are mainly sources of water for livestock and humans, Sand and Talek tributaries are important sources of water for wildlife and some livestock since they traverse the Maasai Mara National Reserve, protected areas and the vast Maasai communal pasture lands [35].

Land use/land cover within the Mara River basin of Kenya therefore transforms through a sequence of zones from highly enclosed canopy forest at the upper portion of the basin through agricultural lands, scattered woodland and shrub land to extensive grasslands in the lowermost portion of the basin before joining Tanzania. The huge number and diversity of mammals, birds, reptiles

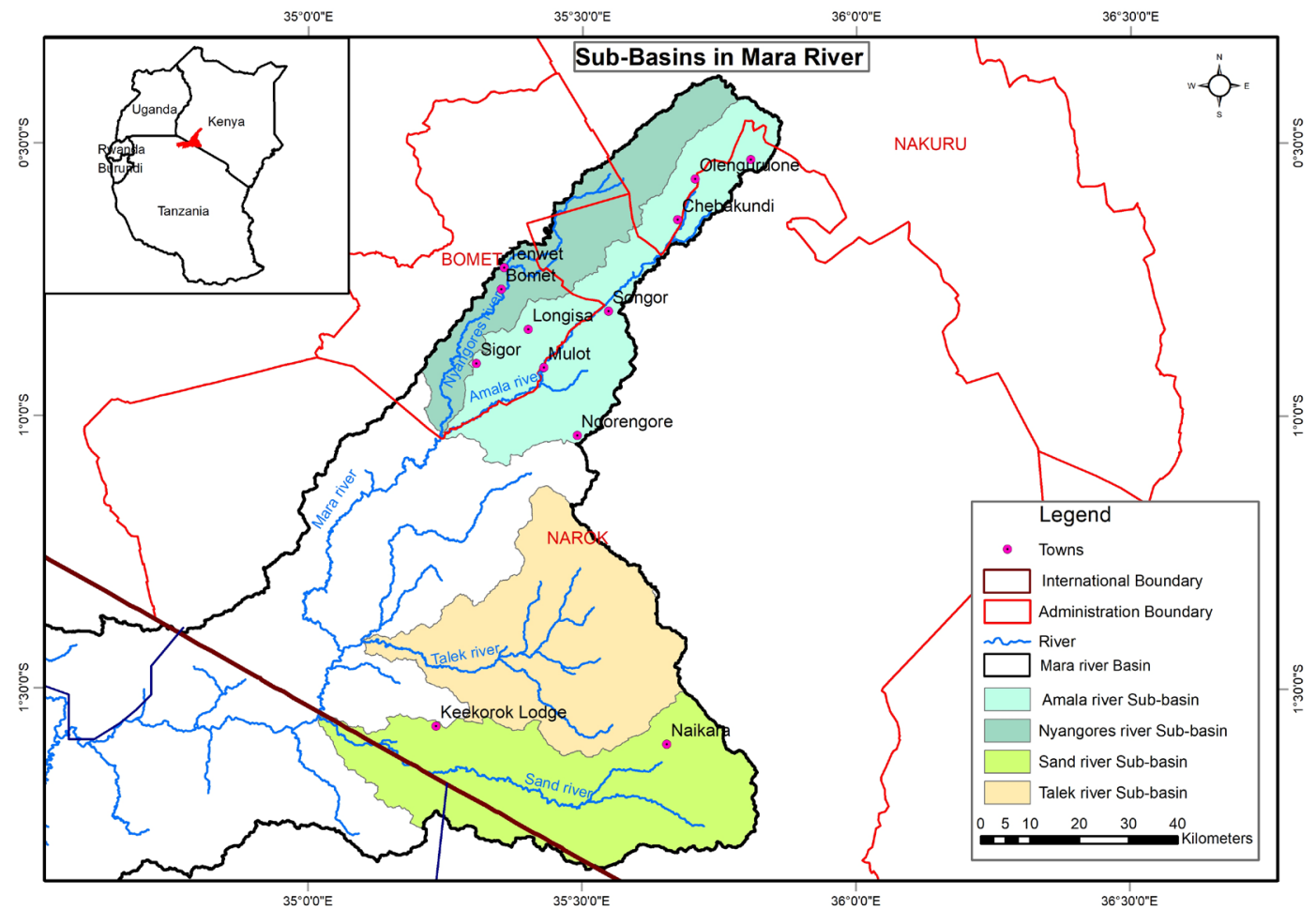

Figure 1. Map of the study area. 
and migratory herbivores including the wildebeests makes the region a major tourist attraction site and an economic hub [35] [36]. The annual wildebeest migration from the Tanzania portion of the Mara Basin into Kenya has even been described by many as the greatest wildlife spectacles on Earth [35] [37].

\subsection{Study Design}

This study adopted a retrospective-empirical study design, combined with a cross-sectional survey that incorporated land cover change detection, household survey and focus group discussions.

\subsubsection{Land Cover Classification and Change Detection}

Land cover change detection was based on comparison of satellite imageries of Landsat Multi-Spectral Scanner for the year 1987, 1997, 2007 and 2017. ERDAS imagine 2013 software was used for image processing and analysis by maximum likelihood supervised classification algorithm. ArcGIS 10.2 was used for mapping and analysis of land cover for all months and years studied. A 16-day MODIS Enhanced Vegetation Index (EVI) composite from MODIS-Terra MOD13Q1 at $250 \mathrm{~m}$ spatial resolution for the four sub-catchments was used for analysis. Ground-truthing was carried out to collect training data samples that guided the image classification process and for accuracy assessment. This was done with the aid of Global Positioning System (GPS) points obtained from specific locations. Thereafter, classified images were coded into respective classes i.e.: water, settlements, croplands, riverine vegetation, grassland and woodland. Spatial variability in vegetation cover was overlaid to depict successive land cover profiles. The NDVI analysis enabled the description of land cover change at decadal intervals.

\subsubsection{Household Survey}

Sampling: To obtain community's view on land cover changes that have occurred over the past 30 years and their impact on livelihoods, a semi-structured questionnaire was designed and the questions translated into Maasai and Kalenjin (the predominant languages in the region) for respondents who were not conversant in English. A sample size of 418 respondents was determined using the Fisher's formula for target population exceeding 10,000, drawn from the four Mara River sub-catchments. A multi-stage sampling method was used in which the 418 respondents, each representing a household, were drawn from the four sub-catchments proportionately based on the size of each sub-catchment (i.e. 152 from Amala, 157 from Nyangores, 70 from Talek and 39 from Sand river sub-catchment). Prior to the survey, the questionnaire was pre-tested in a different river basin (Nyando River Basin) and corrections made to the tool based on the results of the pretest.

Survey approach: The household survey was conducted in the four sub-catchments using a questionnaire with open and closed-ended questions. The survey targeted household heads or their spouses (in their absence). The question- 
naire sought responses to a wide range of socioeconomic aspects among them: 1) household characteristics, 2) land size and duration lived in study area, 3) land use/land cover types and changes that have occurred over time, and 4) impacts of land cover change on household livelihood sources like livestock keeping, crop farming, water availability and accessibility among others. Questionnaire administration lasted for about 45 minutes per respondent. To uphold confidentiality and privacy, respondents who participated in the survey were not identified either by name or by location. The survey was administered in June 2018.

Focus group discussion (FGD): A total of four FGD sessions (one per subcatchment) were conducted. The FGDs were helpful in triangulating the household interviews and contextualizing the study to provide a better understanding of the socio-economic impact of land cover change from the community members' own perspective. The FGD sessions consisted of between 8 - 12 discussants comprising of men, women and youths. A focus group discussion guide containing questions on various aspects of land cover changes and socio-economic wellbeing was used to guide focused discussions. The FGD sessions were conducted in English, Swahili, Maasai or Kalenjin languages depending on the discussants' preference. Each session lasted for about 60 minutes and was tape recorded.

\section{Data Analysis}

\subsection{Land Cover Change}

All GIS data were projected to the Universal Transverse Mercator (UTM) projection system zone $37 \mathrm{~N}$ and datum of World Geodetic System 84 (WGS84), ensuring consistency between data-sets during analysis. The images were analyzed by utilizing data-image-processing techniques in ERDAS Imagine $\odot 10.0$ and ArcGIS $\odot 10.0$ software. Since the identity and location of some of the land-use and land cover types such as grassland, agricultural land, natural forest areas, and eucalyptus plantations in the study area were known, based on the a priori knowledge of the researcher and with ground truthing data, a supervised signature extraction with a maximum likelihood was used in the analysis.

\subsection{Change Detection and Computation}

The change rates of a single land cover type were determined following Peng et al. [38] procedure as shown below:

$$
T 1=\frac{(C b-C a) \times 100 \%}{C a Y}
$$

\section{where:}

$T 1$ : is the land use/cover dynamics degree, measuring the change rate of the target land use/cover type,

$\mathrm{Ca}$ and $\mathrm{Cb}$ : are the area of the target land use/cover type at the beginning and the end of the study period respectively, and

$Y$ : is the study period, which is usually measured with the unit of year. 
Additional analysis was conducted using post-image comparison technique [39]. Ground truthing was complemented with topographical maps of the study area as well as several field visits, and by confirmatory interviews with individuals and elderly people in the area. The classified images were compared in three periods, that is, 1987-1997, 1997-2007 and 2007-2017. The values are presented in terms of hectares and percentages. In addition, trend analysis of rainfall and temperature were conducted. The relationship between rainfall, land surface temperature and land use/land cover change, were also computed.

\subsection{Socio-Economic Survey}

Data obtained through the household survey was coded and analyzed descriptively using the Statistical Package for Social Sciences (SPSS) version 20 (SPSS Inc. 2008). Descriptive statistics namely: cross tabulations, frequencies and percentages were used to summarize data on land cover change and socio-economic variables. The Pearson's chi-square test was used to determine associations between socio-demographical variables and coping strategies. A generalized linear model was used to establish the main drivers of land use/cover in the four sub-catchments.

Focus group discussion recordings were transcribed verbatim from Maasai, Kalenjin or Kiswahili to English. The transcriptions were verified by two independent researchers knowledgeable in the local languages. Content analysis was used to analyze the qualitative data, whereby the discussions from the focus group discussions were objectively and subjectively analyzed [40] and narrated. Text analysis of the transcriptions and the notes taken during the FGDs was conducted by NVivo $10^{\circledR}$ software (QSR International Pty. Ltd., Melbourne, Australia, 2008). Three investigators, each working independently, coded the major themes that emerged from each topic using an inductive approach. Any differences that arose were discussed among the three investigators and a consensus reached.

\section{Results}

The findings emanating from the current study are presented in the sub-sections below.

\subsection{Land Cover Change over the Last 30 Years}

Six key land cover categories were identified in this study. These were: forests, grasslands, shrub-lands, crop lands, bare land and built-up areas. Forests were the dominant land cover type in Amala and Nyangores in 1987 accounting for $39.8 \%$ and $43.7 \%$, respectively. However, 30 years later (2017) acreage under forest cover in the two sub-catchments decreased while crop lands increased significantly from 29,828 acres (21.0\%) in 1987 to 75,574 (53.2\%) in 2017 in Amala sub-catchment and from 21,835 acres (23.3\%) to 42,690 (45.7\%) in 1987 and 2017, respectively, in Nyangores sub-catchment. On the contrary, grasslands 
dominated Talek (52.8\%) and Sand river (47.4\%) sub-catchments in 1987. Thirty years later (2017), grasslands remained the dominant (43.6\%) land cover type within Sand River sub-catchment, while shrub lands replaced grasslands as the dominant land cover in Talek sub-catchment. Over the 1987-2017 period, the area under crop land rose from $0 \%$ to $3.2 \%$, in Talek sub-catchment while bare land increased from $1.4 \%$ to $12.6 \%$, between 1987 and 2017 in Sand river sub-catchment. Built-up area accounted for just $0.01 \%-0.1 \%$ of land cover in Amala and Nyangores sub-catchments, but was negligible in Talek and Sand River sub-catchments (Table 1).

Figures 2-5 show the effect of temperature on land cover change between 1987 and 2017 in the four sub-catchments, based on NDVIs output. Overall, findings show that forested areas had lower temperature differences, ranging

Table 1. Land cover changes between 1987 and 2017 in the four sub-catchments.

\begin{tabular}{|c|c|c|c|c|c|c|c|c|}
\hline \multirow{2}{*}{$\begin{array}{l}\text { Land cover } \\
\text { category }\end{array}$} & \multicolumn{8}{|c|}{ Land cover change in $\mathrm{Ha}(\%)$ across the four sub-catchments } \\
\hline & \multicolumn{2}{|c|}{ Amala } & \multicolumn{2}{|c|}{ Nyangores } & \multicolumn{2}{|c|}{ Talek } & \multicolumn{2}{|c|}{ Sand } \\
\hline Forest & $56,609(39.8 \%)$ & $29,784(21.0 \%)$ & $41,031(43.7 \%)$ & $30,164(32.3 \%)$ & $12,357(7.0 \%)$ & $4939(2.8 \%)$ & $13,955(7.6 \%)$ & $7986(4.4 \%)$ \\
\hline Grassland & $44,269(31.1 \%)$ & $31,550(22.2 \%)$ & $27,681(29.5 \%)$ & $15,997(17.1 \%)$ & $92,493(52.8 \%)$ & $62,708(35.7 \%)$ & $87,106(47.4 \%)$ & $79,884(43.6 \%)$ \\
\hline Shrub Land & $6418(4.5 \%)$ & $2495(1.8 \%)$ & $1014(1.1 \%)$ & $789(0.8 \%)$ & $62,757(35.8 \%)$ & $98,079(55.9 \%)$ & $80,217(43.6 \%)$ & $72,183(39.4 \%)$ \\
\hline Cropland & $29,828(21.0 \%)$ & $75,574(53.2 \%)$ & $21,835(23.3 \%)$ & $42,690(45.7 \%)$ & $0.0(0.0 \%)$ & $5607(3.2 \%)$ & - & - \\
\hline Bare Land & $5068(3.6 \%)$ & $2615(1.8 \%)$ & $2279(2.4 \%)$ & $3721.6(4.0 \%)$ & $7723(4.4 \%)$ & $4244(2.4 \%)$ & $2510(1.4 \%)$ & 22,977 (12.6\%) \\
\hline Built-up areas & $34(0.02 \%)$ & $80(0.06 \%)$ & $47.4(0.01 \%)$ & $105.9(0.1 \%)$ & - & - & - & - \\
\hline
\end{tabular}

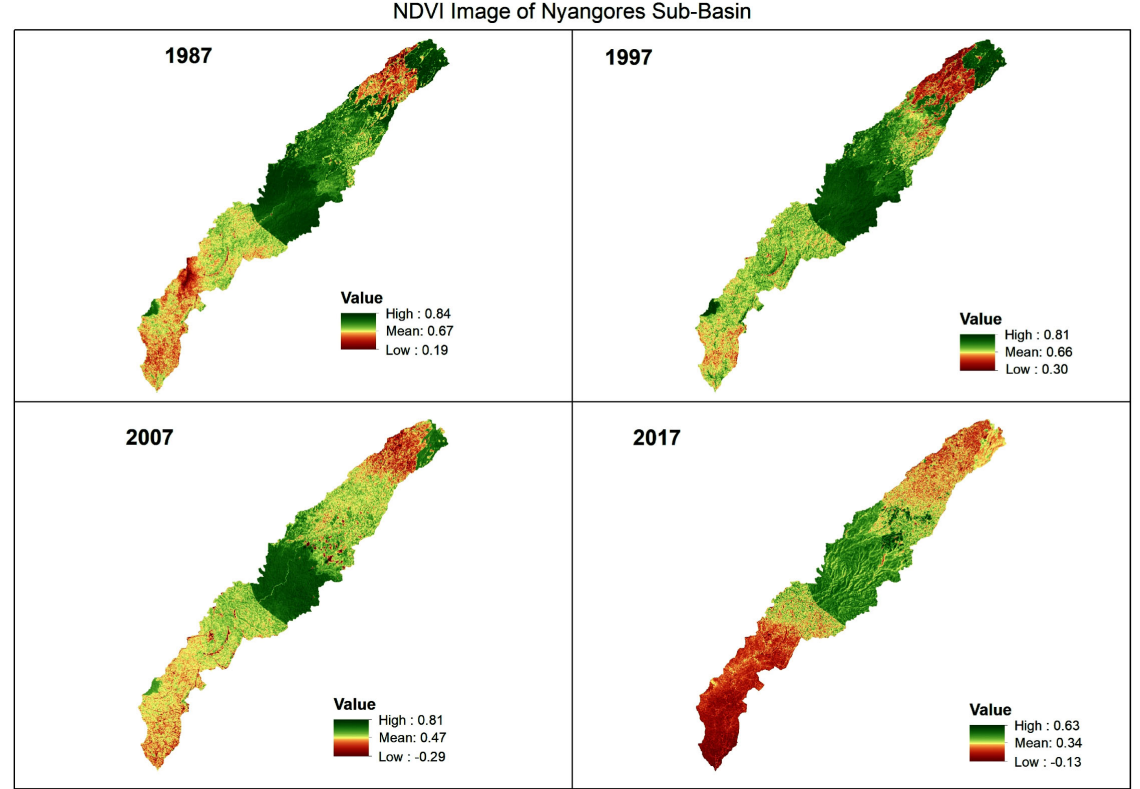

Figure 2. NDVI images of temperature driven land cover change in Nyangores sub-catchment (1987-2017). 


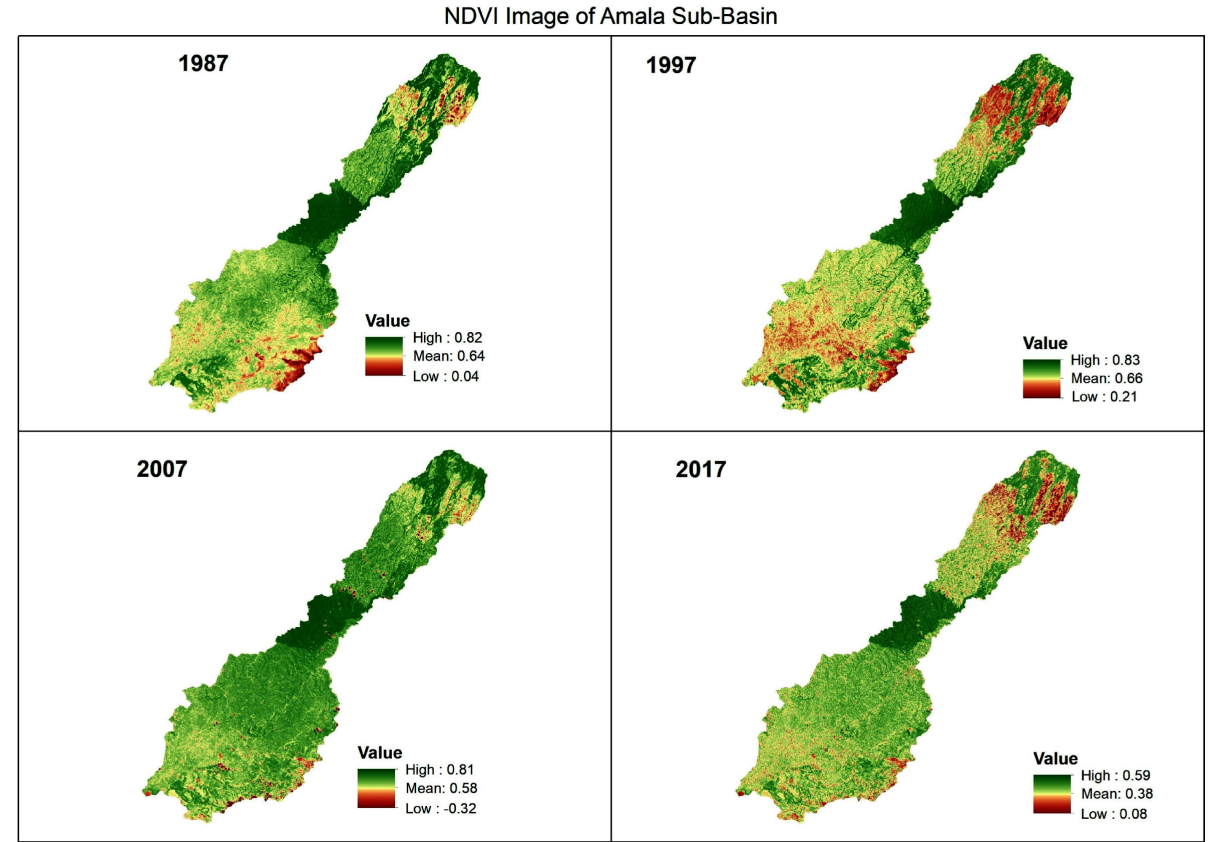

Figure 3. NDVI images of temperature driven land cover change in Amala sub-catchment (1987-2017).

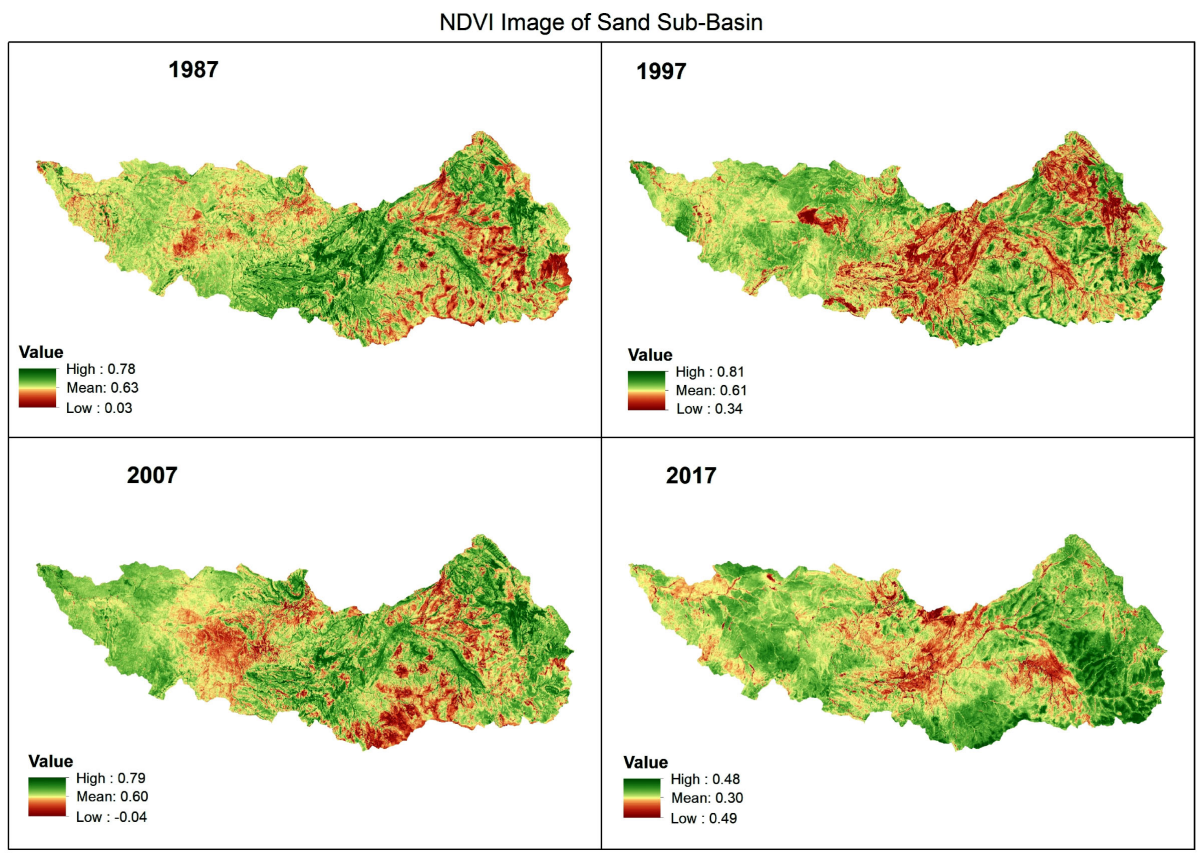

Figure 4. NDVI images of temperature driven land cover change in Sand River sub-catchment (1987-2017).

between $0.2^{\circ} \mathrm{C}-3.0^{\circ} \mathrm{C}$ compared to build-up and bare land areas. The findings also showed that the average temperature and percentage of built up area had a moderate positive correlation $\left(R^{2}=0.57\right)$, compared to bare land $\left(R^{2}=0.44\right)$, shrub land $\left(R^{2}=0.278\right)$, grassland $\left(R^{2}=0.137\right)$, and cropland $\left(R^{2}=0.239\right)$. Likewise, rainfall had a positive correlation with grassland $\left(R^{2}=0.314\right)$, forest cover 


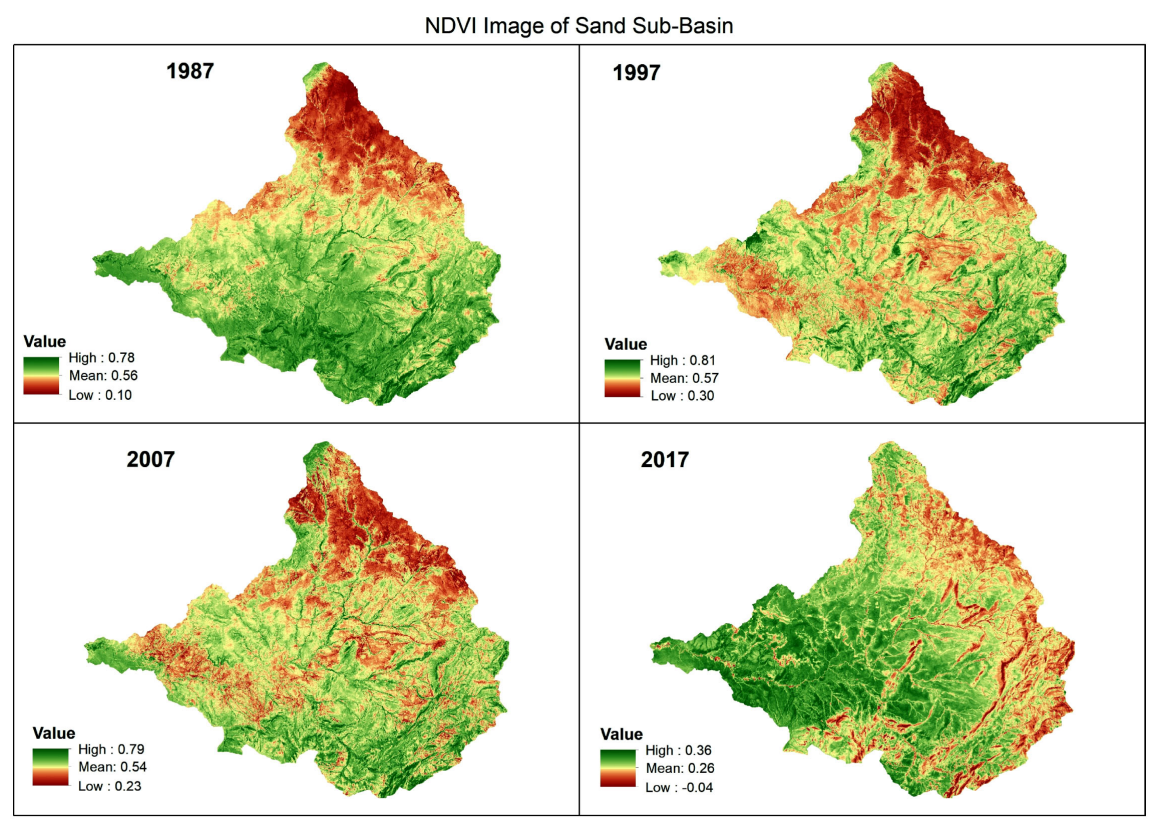

Figure 5. NDVI images of. temperature driven land cover changes in Talek sub-catchment (1987-2017).

$\left(\mathrm{R}^{2}=0.131\right)$, shrub land $\left(\mathrm{R}^{2}=0.0720\right)$ and cropland $\left(\mathrm{R}^{2}=0.256\right)$, and a negative correlation with bare land $\left(\mathrm{R}^{2}=-0.36\right)$, and built up rears $\left(\mathrm{R}^{2}=-0.28\right)$. The analysis results also revealed a difference of temperature between built up and forested areas, with built up areas having about $5.2^{\circ} \mathrm{C}$ higher compared to forested areas.

\subsection{Household Survey Findings}

\section{Household socio-demographic characteristics}

Most respondents $(272,65.1 \%)$ were males whereas females constituted $34.9 \%$ $(\mathrm{n}=146)$. Up to $89.2 \%$ of the respondents were aged between 35 - 65 years, while $5.1 \%$ and $5.7 \%$, were between 25 - 34 years, and 65 years and above, respectively. The number of family members per household ranged from 1 to 7 persons, with the average family size being 5.4 persons. The number persons in the economically dependent age groups (0 - 14) and elderly (65 and above) varied from family to family. Up to $66.1 \%$ of the households had a dependency ratio of between 0.0 and 0.5 , while $33.9 \%$ of had a dependency ratio of between 0.5 and 3. Almost half the household heads (49.8\%) had high school level of education or above, while $38.7 \%$ had primary level of education. However, $11.5 \%$ of the respondents were illiterate. Most (60.3\%) of the surveyed households engaged in mixed farming, while $39.7 \%$ engaged either in some form of business, informal labor or sale of charcoal and firewood.

\section{Previous (1987) and current (2017) dominant life forms}

To establish change in land cover over the 30 year period, respondents were asked to state the land cover types that were present in 1987 against current (2017) situation. The dominant land cover in 1987 as stated by the respondents 
were: shrubs land, crop land, forest cover, pasture land, grasslands and human settlement at $39 \%, 23 \%, 14 \%, 12 \%, 3 \%$ and $8 \%$, respectively. Analysis of the responses for the current period (2017) showed that the proportion of the same land cover types had changed significantly to $3 \%, 38 \%, 17 \%, 20 \%, 13 \%$ and $9 \%$, respectively $\left(\chi^{2}=99.507, \mathrm{df}=5, \mathrm{P} \leq 0.001\right)$. In addition, crop land increased by 15 percentage points, while shrub lands decreased by 36 percentage points over the 30 year period. Responses concerning water bodies however remained unchanged over the study period (Figure 6).

\section{Indicators of land cover change}

Reduction in rain-fed cropland, natural vegetation and communal grazing land was identified by respondents as having contributed most to change in land cover over the 30 year period. Figure 7 depicts shifts in land cover over the 30 year period as reported by study respondents.

\section{Observed changes in land cover over the 30 year period}

Majority of households (89.7\%) reported having noticed changes in natural land cover in their surroundings in the last thirty years. However, $4.9 \%$ of the households did not notice any changes while 5.9\% did not respond. For those who noticed changes in land cover, diminishing vegetation cover was the most common change according to $28.5 \%$ of the respondents. Other changes cited include: conversion of forests to cropland (16.5\%), stunted vegetation growth (12.2 $5 \%$ ), conversion of forest land to bare land (11.7\%), increased weeds on agriculture lands (9.3\%), conversion of forests to human settlements (7.4\%), conversion of forests to pasture lands (7.2\%), selling of forest land to newcomers (3.6\%) and conversion of rain fed cropland to irrigated cropland (1.9\%).

These changes observed over the 30 year period were statistically significant $\left(\chi^{2}=12.41, \mathrm{df}=11, \mathrm{P} \leq 0.001\right)$ (Table 2).

\section{Factors responsible for land cover change}

Study respondents attributed changes in land cover to eight main factors namely; inadequate rainfall (17.9\%), prolonged drought (14.6\%), destruction of catchment areas, (11.2\%), need for increased productivity (9.1\%), increased temperatures (8.9\%), land sub divisions (8.6\%), change in land ownership (8.4\%)

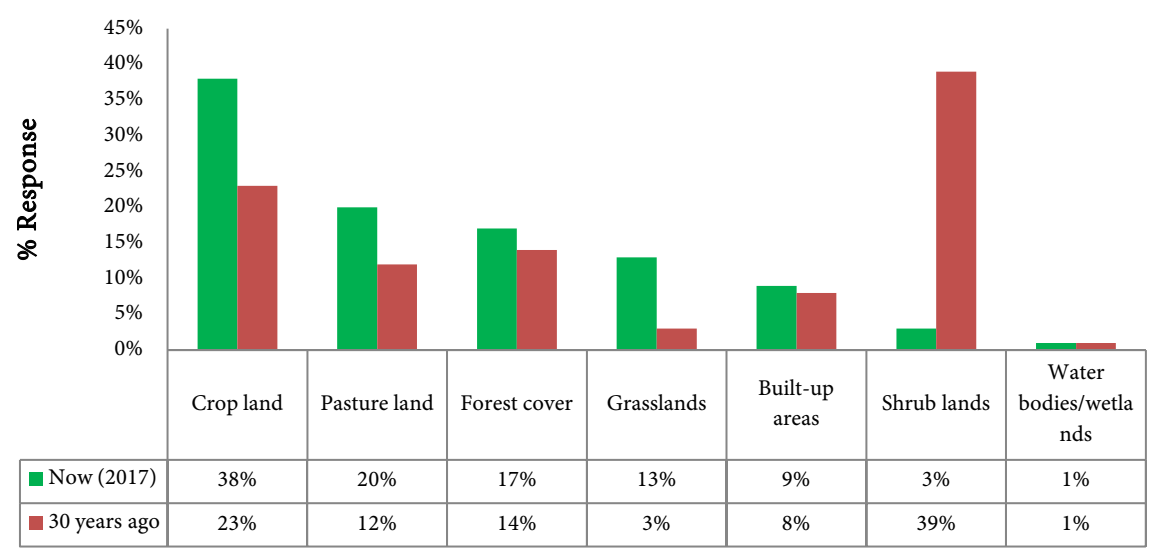

Figure 6. Dominant land cover types in 1987 and 2017 as reported by respondents. 


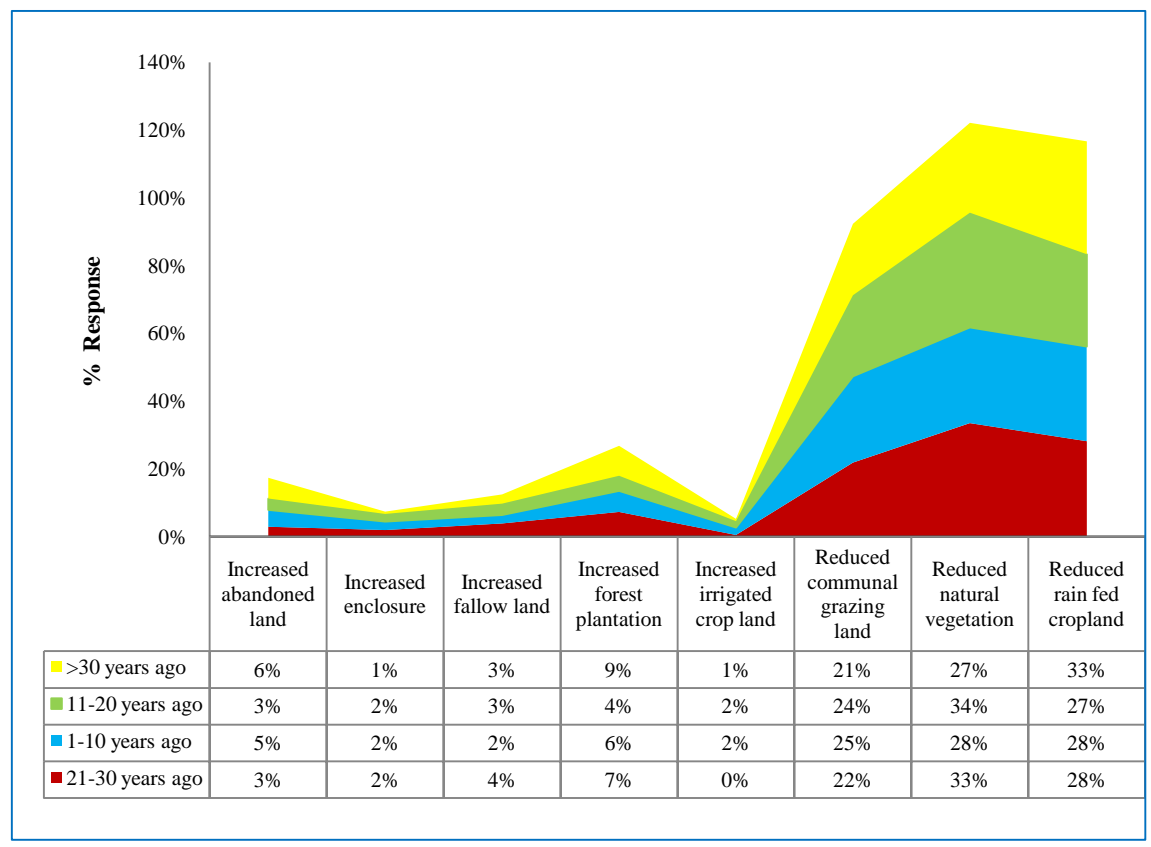

Figure 7. Markers of land cover change over the 30 year period (1987 and 2017).

Table 2. Observed changes in land cover over the 30 year period.

\begin{tabular}{ccc}
\hline & Number & \% Response \\
\hline Diminishing vegetation cover & 119 & 28.5 \\
Conversion of forests to croplands & 69 & 16.5 \\
Stunted vegetation growth & 50 & 12.0 \\
Conversion of forestland/bushland/grassland to bare land & 49 & 11.7 \\
Increase in weeds in agricultural lands & 39 & 9.3 \\
Conversion of forestland to human settlements & 31 & 7.4 \\
Conversion of forestland/bush land to pasture lands & 30 & 7.2 \\
Conversion of forest/ bush land/grassland to bare land & 15 & 3.6 \\
Conversion of rain fed cropland to irrigated crop land & 8 & 1.9 \\
Increase in vegetation cover & 6 & 1.4 \\
Covers ion of forestland/bush land to pasture land & 1 & 0.2 \\
Other changes & 1 & 0.2 \\
Total & 418 & 100
\end{tabular}

and failure to protect rivers (8.1\%). A GLM model of drivers of land cover change showed that increased temperature and human settlements were negatively correlated with land cover change $(P<0.001)$, whereas type of trees planted, household size, education level of household head, wild animals and change in rainfall patterns were positively correlated to land cover change $(\mathrm{P}<$ 0.001 ), and thus considered significant predictors of change in land cover. However, the relationship between land cover change and livestock keeping, 
weak land laws and tourism was not statistically significant $(\mathrm{P}>0.05)$ (Table 3$)$.

\section{Climatic factors and their effect on land cover change}

Majority $(94.5 \%, \mathrm{n}=398)$ of the respondents had noticed changes in temperature patterns, while 5.5\% did not observed any changes over the last 30 years. With regard to seasonal temperature changes, $55 \%$ of the respondents stated that the dry period which used to occur in June and July had shifted to October and November. On changes observed in temperature over the 30 year period, $49.3 \%$ of the respondents felt that some months had became cooler than others, $46.2 \%$ noted that some months had became hotter than normal, while $4.5 \%$ did not respond to the question or did not observe any change. At the sub-catchments level, respondents from Amala $(P=0.003)$, Nyangores $(P<0.001)$, Talek $(P=0.02)$, and Sand River $(\mathrm{P}=0.04)$ concurred that temperature had significantly increased (Fisher's exact test). The perceived causes of the changes observed in temperature and rainfall were deforestation (40.4\%), wind direction (15.6\%), altitude (14.1\%), increase in human settlements (12.4\%) afforestation (9.8\%) and general change in weather patterns (5\%) (Table 4).

To contrast the community's perception and responses concerning changes in climate over the Mara Region, a trend analysis was performed on climate data i.e. temperature and rainfall-spanning 30 years back (1987-2017) and it showed a significant decreasing trend in precipitation and increasing temperature trend over the study duration across all the four sub-catchments.

Respondents in all four sub-catchments felt that grassland, shrub land, tree cover and water sources had diminished significantly due to temperature $\left(\chi^{2}=\right.$ 8.551, $\mathrm{P}=0.0359, \chi^{2}=14.669, \mathrm{P}=0.002122, \chi^{2}=31.299, \mathrm{P}<0.001$ and $\chi^{2}=$ $8.8681, \mathrm{P}=0.0311$, respectively). However, there was no significant difference between those who thought that overgrazing and drying of crops were as a result of temperature change $(P \geq 0.05)$. In addition, those who reported noticing changes in temperature patterns singled out diminishing grasslands, diminishing

Table 3. Generalized Linear Model of land cover change against the identified drivers.

\begin{tabular}{ccccc}
\hline Predictor variable & Estimate & Std. Error & z-value & P-value \\
\hline Intercept & 4.809 & 0.020 & 229.061 & $<0.001$ \\
Types of trees planted & 0.076 & 0.013 & 5.899 & $<0.001$ \\
Level of education & 0.131 & 0.011 & 11.906 & $<0.001$ \\
Livestock keeping & -0.030 & 0.024 & -0.422 & 0.5013 \\
Weak land laws & -0.066 & 0.027 & -0.226 & 0.8212 \\
Household size & 0.155 & 0.011 & 4.880 & 0.0024 \\
Human settlement & -0.066 & 0.014 & -4.592 & $<0.001$ \\
Wild animals & 0.059 & 0.024 & 2.527 & 0.0115 \\
Tourist activities & 0.005 & 0.028 & 0.176 & 0.8606 \\
Change in rainfall pattern & 0.324 & 0.019 & 3.003 & $<0.001$ \\
Increased temperature & -0.209 & 0.010 & -20.822 & $<0.001$ \\
\hline
\end{tabular}


Table 4. Perceived cause of changes in rainfall and temperature in the study area.

\begin{tabular}{ccc}
\hline Variable & Number & \% Response \\
\hline Changes in weather pattern & 21 & 5.0 \\
Afforestation & 41 & 9.8 \\
Increased settlements & 52 & 12.4 \\
Altitude & 60 & 14.4 \\
Wind direction & 65 & 15.6 \\
Deforestation & 169 & 40.4 \\
Don't know & 3 & 0.7 \\
Other factors & 7 & 1.7 \\
Total & 418 & 100 \\
\hline
\end{tabular}

pasture, diminishing shrub land, diminishing tree cover, diminishing water resources (rivers, springs and dams) and drying of crops (Table 5) as some of the effects of temperature changes (standardized residual $\geq 1.5$, Likelihood ratio test $=172.725, \mathrm{df}=16, \mathrm{P}>0.001)$.

With a chi-square test statistic $\left(\chi^{2}=408.753\right)$ being $\mathrm{P}=00034$ and therefore less than the alpha level of significance of 0.05 , the $z$-score of those who reported diminishing tree cover, shrub land and grass lands were (3.5), (2.8) and (2.6), respectively, which was higher than the critical value (1.96). This supported the observation by the surveyed households who noticed changes in rainfall and its effects on land cover (Table 6). From the results, fewer survey households than expected (standardized residual $=-3.4$ ) stated that deforestation affected temperature change and increased river flow. However, a good proportion of them indicated that increase in observed temperature affected rivers mainly due to changes in weather pattern (1.9) and deforestation (1.2). This therefore supports the argument that deforestation actually affected river flow (Table 7).

\section{Implication of changes in rainfall on land cover}

With regard to rainfall, $96.4 \%$ of the 418 respondents across the four sub-catchments reported noticing some changes in rainfall patterns. The most commonly cited indicator was unpredictable rainfall pattern (43.1\%). Others included shifts in rainfall pattern, too little rainfall leading to prolonged droughts and disappearing of some species of vegetation, accounting for $28.3 \%, 17.5 \%$ and $11.2 \%$, respectively. The observed changes were significantly different across the four sub-catchments $\left(\chi^{2}=11.587, \mathrm{df}=3, \mathrm{P}<0.008939\right)$. On the perceived cause of changes in rainfall pattern, $46.2 \%$ of respondents cited deforestation, $28 \%$ cited change of weather pattern and $14 \%$ cited altitude as the main cause of change in rainfall patterns. Almost all (96.9\%) respondents reported that changes in rainfall patterns had an effect on land cover, while $7.2 \%$ felt that change in rainfall patterns increased vegetation cover. Most respondents were in agreement that cutting down of trees was worsening the rainfall patterns in the area. Responses on impact of changes in rainfall patterns on water resources are shown in Table 8. 
Table 5. Effect of temperature change on different land cover types in the four sub-catchments.

\begin{tabular}{ccccccc}
\hline & Amala & Nyangores & Sand river & Talek & $\chi^{2}$ test $(\mathrm{df}=3)$ & Total \\
\hline Diminishing grassland & $30(38.9 \%)$ & $25(32.5 \%)$ & $8(10.4 \%)$ & $14(18.2 \%)$ & $8.551, \mathrm{P}=0.0359$ & 77 \\
Diminishing pasture & $23(31.1 \%)$ & $19(25.7 \%)$ & $14(18.9 \%)$ & $18(24.3 \%)$ & $1.475, \mathrm{P}=0.688$ & 74 \\
Diminishing shrub-land & $16(28.6 \%)$ & $24(42.9 \%)$ & $5(8.9 \%)$ & $11(19.6 \%)$ & $14.669, \mathrm{P}=0.0021$ & 56 \\
Diminishing tree cover & $42(39.3 \%)$ & $47(43.9 \%)$ & $5(4.7 \%)$ & $13(12.1 \%)$ & $31.299, \mathrm{P}<0.001$ & 107 \\
Diminishing water resources & $21(36.8 \%)$ & $19(33.3 \%)$ & $5(8.8 \%)$ & $12(21.1 \%)$ & $8.8681, \mathrm{P}<0.031$ & 57 \\
Drying crops & $20(42.6 \%)$ & $23(48.9 \%)$ & $2(4.3 \%)$ & $2(4.3 \%)$ & $0.1315, \mathrm{P}=0.5816$ & 47 \\
Total & $\mathbf{1 5 2}$ & $\mathbf{1 5 7}$ & $\mathbf{3 9}$ & $\mathbf{7 0}$ & $\mathbf{4 1 8}$ \\
\hline
\end{tabular}

Table 6. Effects of temperature on select indicators of land cover change.

\begin{tabular}{|c|c|c|c|c|c|c|c|c|c|c|c|}
\hline \multirow{2}{*}{\multicolumn{2}{|c|}{$\begin{array}{l}\text { Responses on whether or } \\
\text { not temp affect changes in } \\
\text { land cover }\end{array}$}} & \multicolumn{9}{|c|}{ Effect of temperature change } & \multirow[b]{2}{*}{ Total } \\
\hline & & \multirow{2}{*}{$\begin{array}{c}\text { Diminishing } \\
\text { grasslands } \\
5\end{array}$} & \multirow{2}{*}{$\begin{array}{c}\text { Diminishing } \\
\begin{array}{c}\text { pasture due to } \\
\text { overgrazing }\end{array} \\
2\end{array}$} & \multirow{2}{*}{$\begin{array}{c}\text { Diminishing } \\
\text { shrub land } \\
0\end{array}$} & \multirow{2}{*}{$\begin{array}{c}\text { Diminishing } \\
\text { tree cover } \\
4\end{array}$} & \multirow{2}{*}{ 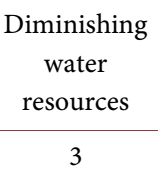 } & \multirow{2}{*}{$\begin{array}{l}\text { Drying of } \\
\text { crops } \\
1\end{array}$} & \multirow{2}{*}{$\begin{array}{c}\text { No } \\
\text { response } \\
5\end{array}$} & \multirow{2}{*}{$\begin{array}{c}\text { N/A } \\
0\end{array}$} & \multirow{2}{*}{$\begin{array}{c}\text { Other } \\
\text { specified } \\
\text { influence }\end{array}$} & \\
\hline & Count & & & & & & & & & & 20 \\
\hline $\begin{array}{c}\text { No } \\
\text { response }\end{array}$ & Residual & 1.3 & -1.2 & -2.7 & 0 & 0.3 & -1.2 & 4.6 & -1.1 & 0 & \\
\hline & Std. Residual & 0.7 & -0.7 & -1.6 & 0 & 0.2 & -0.8 & 7.5 & -1 & -0.2 & \\
\hline & Count & 0 & 0 & 0 & 0 & 1 & 0 & 1 & 20 & 0 & 22 \\
\hline No & Residual & -4.1 & -3.5 & -2.9 & -4.4 & -2 & -2.5 & 0.6 & 18.8 & -0.1 & \\
\hline & Std. Residual & -2 & -1.9 & -1.7 & -2.1 & -1.2 & -1.6 & 0.9 & 17.5 & -0.2 & \\
\hline & Count & 72 & 64 & 56 & 80 & 53 & 46 & 2 & 2 & 1 & 376 \\
\hline & Std. Residual & 0.3 & 0.6 & 0.8 & 0.5 & 0.2 & 0.6 & -1.9 & -4 & 0.1 & \\
\hline Total & Count & 77 & 66 & 56 & 84 & 57 & 47 & 8 & 22 & 1 & 418 \\
\hline
\end{tabular}

Table 7. Effect of temperature change on water quantity and flow in rivers.

\begin{tabular}{|c|c|c|c|c|c|c|c|c|c|c|c|c|}
\hline $\begin{array}{c}\text { Effect of } \\
\text { temperature } \\
\text { change on rivers }\end{array}$ & & 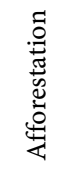 & 营 & 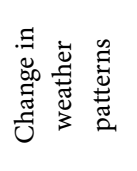 & 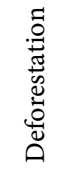 & 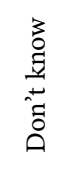 & 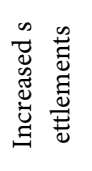 & 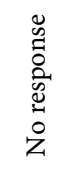 & $\overleftrightarrow{Z}$ & 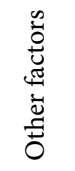 & 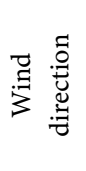 & $\underset{H}{\stackrel{\pi}{0}}$ \\
\hline \multirow{3}{*}{$\begin{array}{c}\text { Decrease of river } \\
\text { flow }\end{array}$} & Count & 6 & 29 & 0 & 63 & 1 & 18 & 0 & 3 & 12 & 20 & 152 \\
\hline & Residual & -6 & 7.2 & -0.4 & 1.5 & -0.1 & -0.9 & -2.2 & 0.1 & 4.4 & -3.6 & \\
\hline & Std. Residual & -1.7 & 1.5 & -0.6 & 0.2 & -0.1 & -0.2 & -1.5 & 0.1 & 1.6 & -0.7 & \\
\hline \multirow{3}{*}{$\begin{array}{l}\text { Drying up of } \\
\text { rivers }\end{array}$} & Count & 6 & 12 & 0 & 54 & 1 & 14 & 1 & 3 & 2 & 20 & 113 \\
\hline & Residual & -2.9 & -4.2 & -0.3 & 8.3 & 0.2 & -0.1 & -0.6 & 0.8 & -3.7 & 2.4 & \\
\hline & Std. Residual & -1 & -1 & -0.5 & 1.2 & 0.2 & 0 & -0.5 & 0.6 & -1.5 & 0.6 & \\
\hline \multirow{3}{*}{$\begin{array}{l}\text { Drying up of } \\
\text { water pans }\end{array}$} & Count & 8 & 14 & 1 & 30 & 0 & 16 & 0 & 0 & 2 & 8 & 79 \\
\hline & Residual & 1.8 & 2.7 & 0.8 & -1.9 & -0.6 & 6.2 & -1.1 & -1.5 & -2 & -4.3 & \\
\hline & Std. Residual & 0.7 & 0.8 & 1.9 & -0.3 & -0.8 & 2 & -1.1 & -1.2 & -1 & -1.2 & \\
\hline \multirow{3}{*}{$\begin{array}{c}\text { Increase of river } \\
\text { flow }\end{array}$} & Count & 12 & 1 & 0 & 20 & 0 & 4 & 3 & 0 & 1 & 17 & 58 \\
\hline & Residual & 7.4 & -7.3 & -0.1 & -3.4 & -0.4 & -3.2 & 2.2 & -1.1 & -1.9 & 8 & \\
\hline & Std. Residual & 3.5 & -2.5 & -0.4 & -0.7 & -0.6 & -1.2 & 2.4 & -1.1 & -1.1 & 2.7 & \\
\hline
\end{tabular}




\section{Continued}

\begin{tabular}{|c|c|c|c|c|c|c|c|c|c|c|c|c|}
\hline & Count & 1 & 0 & 0 & 2 & 0 & 0 & 2 & 0 & 0 & 0 & 5 \\
\hline \multirow[t]{3}{*}{ No response } & Residual & 0.6 & -0.7 & 0 & 0 & 0 & -0.6 & 1.9 & -0.1 & -0.3 & -0.8 & \\
\hline & Std. Residual & 1 & -0.8 & -0.1 & 0 & -0.2 & -0.8 & 7.2 & -0.3 & -0.5 & -0.9 & \\
\hline & Count & 0 & 3 & 0 & 0 & 1 & 0 & 0 & 2 & 3 & 0 & 9 \\
\hline \multirow[t]{3}{*}{ N/A } & Residual & -0.7 & 1.7 & 0 & -3.6 & 0.9 & -1.1 & -0.1 & 1.8 & 2.5 & -1.4 & \\
\hline & Std. Residual & -0.8 & 1.5 & -0.1 & -1.9 & 3.7 & -1.1 & -0.4 & 4.4 & 3.8 & -1.2 & \\
\hline & Count & 0 & 1 & 0 & 0 & 0 & 0 & 0 & 0 & 1 & 0 & 2 \\
\hline \multirow[t]{2}{*}{ Other effects } & Residual & -0.2 & 0.7 & 0 & -0.8 & 0 & -0.2 & 0 & 0 & 0.9 & -0.3 & \\
\hline & Std. Residual & -0.4 & 1.3 & -0.1 & -0.9 & -0.1 & -0.5 & -0.2 & -0.2 & 2.8 & -0.6 & \\
\hline Total & Count & 33 & 60 & 1 & 169 & 3 & 52 & 6 & 8 & 21 & 65 & 418 \\
\hline
\end{tabular}

Source: Survey data (2018).

Table 8. Impacts of changes in rainfall patterns on land cover and water resources.

\begin{tabular}{|c|c|c|c|c|c|c|c|c|}
\hline $\begin{array}{c}\text { Indicators for changes in } \\
\text { rainfall }\end{array}$ & & $\begin{array}{c}\text { Decreased } \\
\text { water quantity }\end{array}$ & $\begin{array}{c}\text { Increases water } \\
\text { pollution }\end{array}$ & $\begin{array}{c}\text { Increases water } \\
\text { quantities }\end{array}$ & No response & $\mathrm{N} / \mathrm{A}$ & $\begin{array}{l}\text { Reduces river } \\
\text { pollution }\end{array}$ & Total \\
\hline \multirow{3}{*}{$\begin{array}{c}\text { Disappearance of some } \\
\text { vegetation species }\end{array}$} & Count & 20 & 20 & 9 & 0 & 0 & 5 & 54 \\
\hline & Residual & -0.9 & 2 & -0.9 & -0.5 & -0.6 & 1 & \\
\hline & Std. Residual & -0.2 & 0.5 & -0.3 & -0.7 & -0.8 & 0.5 & \\
\hline \multirow{3}{*}{$\begin{array}{l}\text { High frequency of heavy } \\
\text { rains leading to flooding }\end{array}$} & Count & 10 & 9 & 4 & 0 & 0 & 2 & 25 \\
\hline & Residual & 0.3 & 0.7 & -0.6 & -0.2 & -0.3 & 0.1 & \\
\hline & Std. Residual & 0.1 & 0.2 & -0.3 & -0.5 & -0.5 & 0.1 & \\
\hline \multirow{3}{*}{ No response } & Count & 0 & 2 & 3 & 1 & 0 & 1 & 7 \\
\hline & Residual & -2.7 & -0.3 & 1.7 & 0.9 & -0.1 & 0.5 & \\
\hline & Std. Residual & -1.6 & -0.2 & 1.5 & 3.6 & -0.3 & 0.7 & \\
\hline \multirow{3}{*}{$\mathrm{N} / \mathrm{A}$} & Count & 0 & 0 & 0 & 0 & 3 & 0 & 3 \\
\hline & Residual & -1.2 & -1 & -0.6 & 0 & 3 & -0.2 & \\
\hline & Std. Residual & -1.1 & -1 & -0.7 & -0.2 & 15.6 & -0.5 & \\
\hline \multirow{4}{*}{ Other indicators } & Count & 1 & 0 & 0 & 0 & 0 & 0 & 1 \\
\hline & Residual & 0.6 & -0.3 & -0.2 & 0 & 0 & -0.1 & \\
\hline & Std. Residual & 1 & -0.6 & -0.4 & -0.1 & -0.1 & -0.3 & \\
\hline & Count & 46 & 40 & 24 & 0 & 0 & 7 & 117 \\
\hline \multirow[t]{3}{*}{ Shift in rainfall seasons } & Residual & 0.7 & 1.1 & 2.4 & -1.1 & -1.4 & -1.7 & \\
\hline & Std. Residual & 0.1 & 0.2 & 0.5 & -1.1 & -1.2 & -0.6 & \\
\hline & Count & 38 & 28 & 2 & 1 & 0 & 4 & 73 \\
\hline \multirow[t]{2}{*}{$\begin{array}{c}\text { Too little rainfall leading to } \\
\text { prolonged droughts }\end{array}$} & Residual & 9.7 & 3.7 & -11.4 & 0.3 & -0.9 & -1.4 & \\
\hline & Std. Residual & 1.8 & 0.8 & -3.1 & 0.4 & -0.9 & -0.6 & \\
\hline \multirow{3}{*}{$\begin{array}{l}\text { Unpredictable } \\
\text { rainfall patterns }\end{array}$} & Count & 47 & 40 & 35 & 2 & 2 & 12 & 138 \\
\hline & Residual & -6.5 & -5.9 & 9.6 & 0.7 & 0.3 & 1.8 & \\
\hline & Std. Residual & -0.9 & -0.9 & 1.9 & 0.6 & 0.3 & 0.6 & \\
\hline Total & Count & 162 & 139 & 77 & 4 & 5 & 31 & 418 \\
\hline
\end{tabular}




\section{Impacts of Land Cover Change on Socio-Economic Wellbeing Impact of land cover change on livestock production}

Livestock is an important sector of the rural economy in the four sub-catchments studied. Results showed that $95 \%$ of the households kept some livestock. Most households kept cattle (90.9\%), goats (58.6\%) and sheep (57.2\%). Chicken and other poultry were majorly kept for food (41.1\%). Goats and sheep had almost equal percentage of responses for both food and sale at $27.8 \%$ and $29.7 \%$, respectively. Camels and donkeys were mostly kept for transportation and farm power whereas bees were majorly kept for honey production. Only a small proportion (1\%) of households kept pigs, rabbits and ducks. All communities, including the nomads, pastoralists and sedentary communities in the four sub-catchments have relied on vegetation and natural pasture for their livestock over the past 30 year.

Responses on the effect of land cover change on livestock production varied among respondents. Whilst $43.9 \%$ believed that changes in land cover affected livestock in their region, $19.6 \%$ thought otherwise, while $0.2 \%$ did not know and $4.1 \%$ did not respond to the question. Another $32.8 \%$ felt that the question was not applicable to them. Nevertheless, there was a general consensus that decreased levels of rainfall and prolonged droughts in recent times had impacted on livestock production. Respondents mentioned diminishing grasslands (29.7\%), diminishing pasture (20.3\%), diminishing shrub land (14.8\%), diminishing tree cover $(17 \%)$, diminishing water resources (11.7\%) among others as some of the effects of livestock production and climatic factors on land cover (Table 9).

About $92 \%$ of the respondents reported noticing nomadic movements in the region due to shortage of pasture and water. More than half (53\%) the respondents however felt that these nomadic movements had severely degraded pastures, while

Table 9. Impact of climatic factors and livestock production on land cover.

\begin{tabular}{ccc}
\hline & Number & \% Response \\
\hline Diminishing grasslands & 124 & 29.7 \\
Diminishing pasture due to overgrazing & 85 & 20.3 \\
Diminishing tree cover & 71 & 17.0 \\
Diminishing shrub land & 62 & 14.8 \\
Diminishing water resources & 49 & 11.7 \\
Improved grasslands & 8 & 1.9 \\
Improved pasture & 8 & 1.9 \\
Improved water sources & 6 & 1.4 \\
Improved tree cover & 3 & 0.7 \\
Improved shrub land & 1 & 0.2 \\
Other changes & 1 & 0.2 \\
Total & 418 & 100.0 \\
\hline
\end{tabular}


others associated loss of some vegetation species to overgrazing. Of the $3.6 \%$ of respondents who did not keep livestock, 35\% of them cited lack of water, $26 \%$ lack of pasture land and $22 \%$ unfavorable climate as the reasons for not keeping livestock (Figure 8).

A large proportion (95.5\%) of households believed that changes in land cover affected livestock production. The most commonly cited indicators of change in livestock production were; reduced production (34\%), increased prevalence of livestock diseases (28.7\%), livestock deaths (18.7\%), livestock wasting away $(12 \%)$ and others (6.7\%). Additional factors attributed to changes in livestock production besides changes in land cover were: lack of water (26.6\%), prolonged drought (33.5\%), increase in diseases (33.3\%) and frequent flooding (4.5\%). Most households (90.7\%) believe that animal production had considerable effect on land cover change. Over half (54\%) the respondents reported having been affected negatively, while $21 \%$ were affected positively (Figure 9 ).

Up to $89.5 \%$ of the respondents believed that animal production had a considerable negative effect on rivers in the region. Water pollution through river

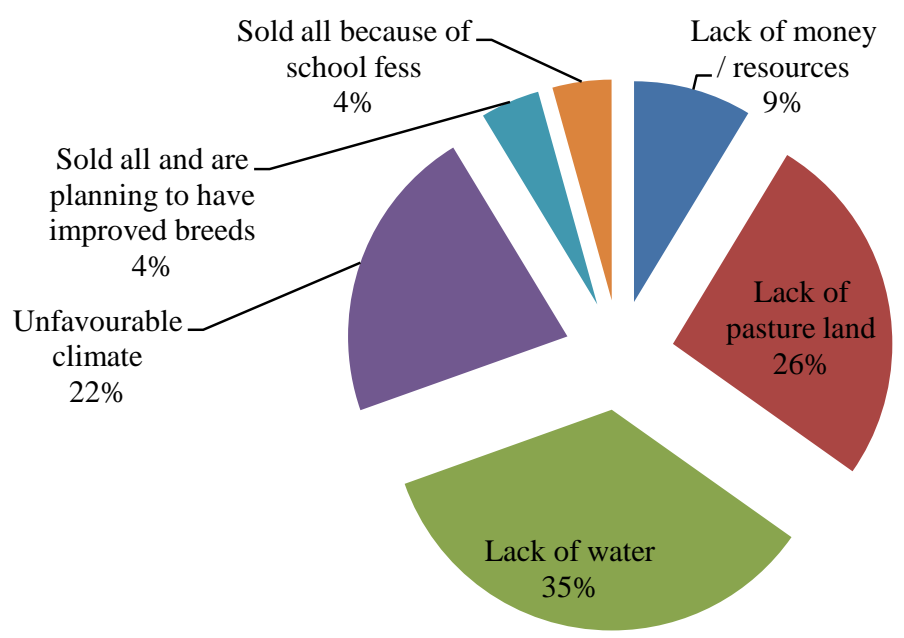

Figure 8. Reason given for not keeping livestock.

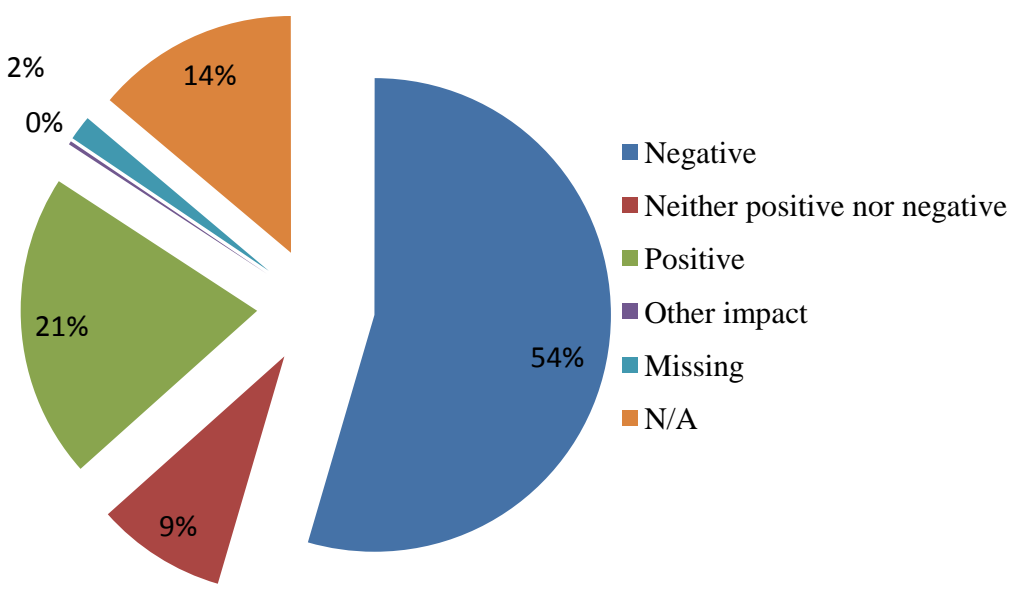

Figure 9. Impact of livestock production on community member's livelihood. 
bank erosion was the most commonly cited effect of animal production on rivers, followed by increased sediment load and reduced amount of water in that order (Figure 10).

\section{Impact of climate and land cover change on crop production}

Vegetables, cereals, legumes, tubers, fruits and cash crops were some of the crops grown within the study area. Of these, vegetables were the most commonly stated type of crop accounting for $37.8 \%$ of the responses followed by cereals and legumes each at $18.7 \%$ and $15.1 \%$, respectively (Table 10 ).

Low and declining rainfall, land and soil degradation, over grazing, cultivation without rest periods and poor traditional land tenure systems, were cited as major constraints to crop production in the studied sub-catchments. Most (79.4\%) respondents reported witnessing insufficient crop yields over the last 30 years, largely because of rainfall variability, land degradation and a lack of extension services. Pearson correlation coefficients for annual precipitation Coefficient of Variation (CV) against crop yield for the period 1987-2017 revealed negative correlations for most common basic food crops: i.e. maize $(\mathrm{r}=-0.587)$, beans $(\mathrm{r}$ $=-0.5459)$, sorghum $(\mathrm{r}=-0.351)$, cow peas $(\mathrm{r}=-0.544)$, and pigeon peas $(\mathrm{r}=$ -0.337). Shifts in seasons (35.3\%), deforestation (30.7\%), loss of fertility (13.0), increase in pests and weeds (12.7\%), drought (5.6\%) among others were cited as responsible for the reduction in crop production (Figure 11).

On further investigation to establish whether respondents attributed the decrease in crop production to land cover change, $35.1 \%$ of households stated that deforestation exposes soil, making it easily erodible, $27.4 \%$ stated diminishing vegetation cover exacerbating droughts, $23.5 \%$ reported increase in weeds that chock food crops and $11.9 \%$ reported excessive uptake of water by alien plant species which dries up the area (Figure 12).

Diminishing crop yield had a direct effect on $62.9 \%$ of the respondents across the four sub-catchments. However, for those households that were not affected, $61.7 \%$ reported buying food always, whereas $29.9 \%$ had alternative sources of food.

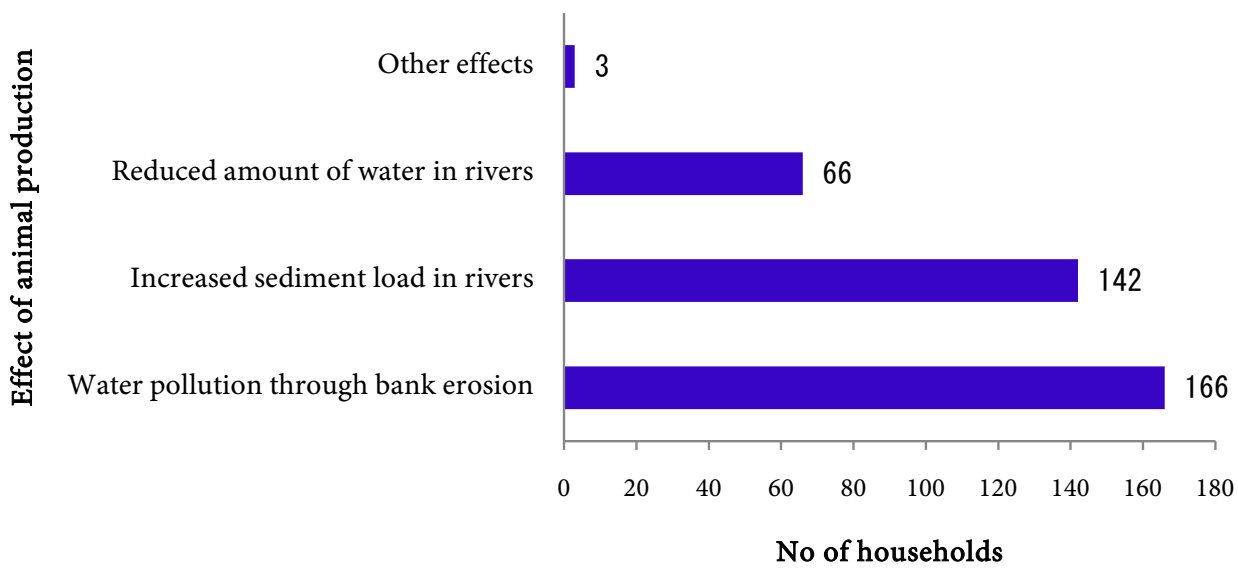

Figure 10. Effects of livestock production on rivers. 


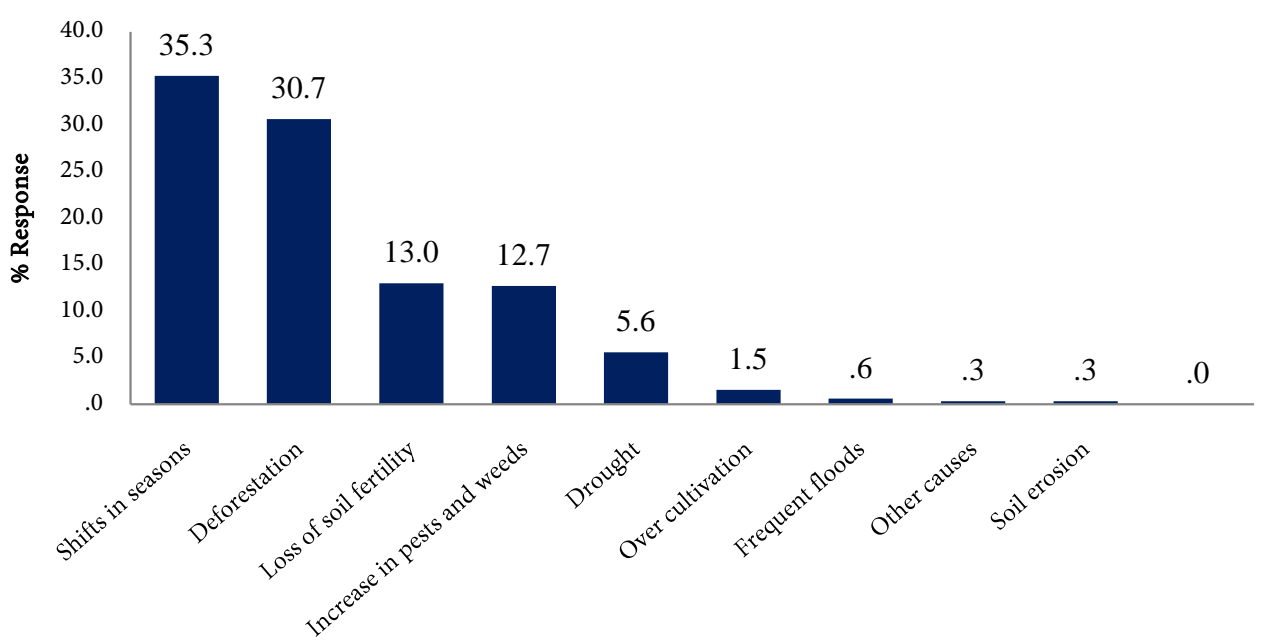

Figure 11. Causes of decrease in crop production within the study area.

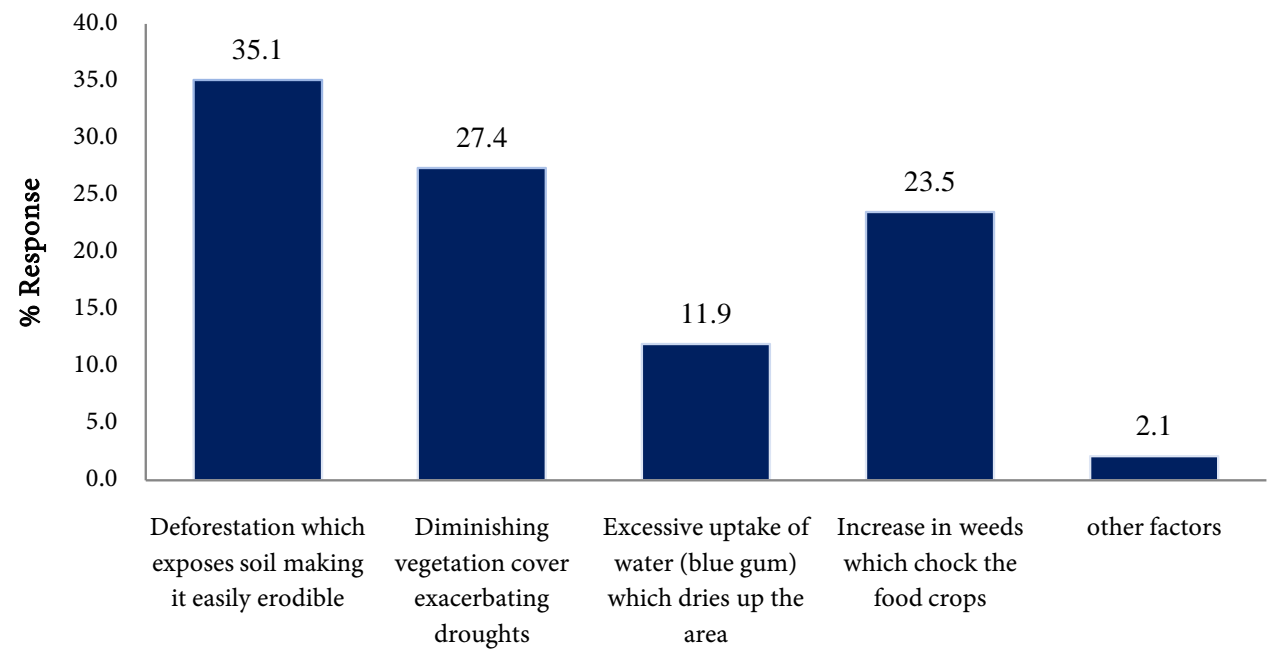

Figure 12. Land cover changes and climatic factors affecting crop production.

Table 10. Crops grown within the study area.

\begin{tabular}{ccc}
\hline Variables & Number & \% Response \\
\hline Vegetables & 158 & 37.8 \\
Cereals & 78 & 18.7 \\
Legumes & 63 & 15.1 \\
Tubers & 51 & 12.2 \\
Fruits & 41 & 9.8 \\
Cash crops & 24 & 5.7 \\
No response & 3 & 0.7 \\
Total & 418 & 100.0
\end{tabular}

Extent and severity of land degradation within the study area

The proportion of respondents that reported very severe degradation in land 
cover 30 years ago, 21 - 30 years ago, 11 - 20 years ago, 1 - 10 years ago and now were $1 \%, 3 \%, 5 \%, 6 \%$ and $19 \%$, respectively, depicting a steadily increasing trend. Generally, the proportion of respondents who reported no degradation 30 years ago declined from 33\% in 1987 to 6\% now (2017). Land degradation on vulnerable land units was reported by most respondents (43\%) while $22 \%$ reported widespread degradation everywhere. The most common causes of land degradation were population growth $(92.1 \%)$ and poor land use practice $(38.3 \%)$, over grazing (29.2\%) among others. Major land management initiatives practiced in the localities were; afforestation, agro forestry, soil and water conservation and land reclamation, according to $29.2 \%, 22 \%, 21.5 \%, 12.7 \%$ and $5 \%$ of the respondents, respectively. Government institutions were the most involved in land management issues in the region. However, almost half the respondents felt that these organizations were not effective, with $37 \%$ of them citing underfunding as the reason for their ineffectiveness.

\section{Impact of climatic factors and land cover change on water resources}

Reduction in the availability of water was apparent in all the sub-catchments going by the responses received. Obtaining clean water for drinking from nearby streams and rivers was cited as among the biggest challenge facing water resources accessibility. According to respondents, the main cause of water reduction was lack of rainfall as a result of the cutting down of trees. Almost all (96.4\%) respondents associated decrease in river flow to increase in temperature. High temperatures were responsible for decrease in river flow (36.4\%), drying up of water pans and drying up of rivers and their tributaries $\left(\chi^{2}=40.685, \mathrm{df}=3\right.$, $\mathrm{P} \leq 0.001)$ (Table 11).

Change in rainfall patterns was reported to affect water resources by $98.1 \%$ of the respondents. Of these, $38.8 \%$ cited decreased water quantity, 33.3\% reported increased pollution into rivers, while the rest mentioned increase in respiratory diseases. A large proportion of household respondents $(78.1 \%)$ cited declining rainfall $(32.3 \%)$ as the major contributor to water shortages whilst $43 \%$ attributed water shortage to disappearance of forest cover. Over $68.2 \%$ of respondents mentioned animal deaths as major consequences to decreasing rainfall.

\section{Socio-economic implications of climatic and land cover change}

Results showed that $97.4 \%$ of the respondents believed that changes in rainfall

Table 11. Changes observed in water resources availability over the 30 year period.

\begin{tabular}{ccc}
\hline Variable & Number & \% response \\
\hline Drying up of tributaries & 67 & 16.0 \\
Drying up of water pans & 86 & 20.6 \\
Drying up of rivers & 113 & 27.0 \\
Decrease in river flow & 152 & 36.4 \\
Total & 418 & 100 \\
$\chi^{2}$ test & & $\mathrm{P}<0.001$ \\
\hline
\end{tabular}


patterns affected the socio economic well-being of people in their area through increased diseases resulting in high health care cost (39.3\%), increase in cost of water treatment $(25.8 \%)$ and decrease in crop yields resulting in low household income (16\%). Few respondents (9.8\%) cited increased yield resulting in high income and decrease in diseases $(7.2 \%)$. There were varied responses on indicators of changes in rainfall pattern. For instance, 34.2\% $(n=40)$ of respondents in Amala sub-catchment, 45.3\% $(\mathrm{n}=53)$ in Nyangores, $12.8 \%(\mathrm{n}=15)$ in Sand River and $16.2 \%(\mathrm{n}=19)$ in Talek sub-catchment mentioned unpredictable rainfall as a major indicator of change in rainfall patterns. Other indicators mentioned include: disappearance of some species of vegetation, heavy rains leading to flooding, too little rainfall leading to prolonged droughts and shift in rainfall seasons (Table 12). A chi-square test statistic $\left(\mathrm{n}=418, \mathrm{df}=5, \chi^{2}=408.753, \mathrm{P}=\right.$ 00034) supported the notion among the surveyed respondents on the changes that they had noticed concerning changes in rainfall pattern in the four sub catchments.

\section{Effect of climate and land cover change on human health}

Change in land cover has an impact on human health as reported by $84.2 \%$ of the respondents. On the contrary, $14.6 \%$ stated that the changes did not have any human health implications. Majority (68.2\%) of the respondents reported an increase in malaria fever and malnutrition due to land cover change while $15.3 \%$ reported a decrease in malnutrition and malaria incidences as a result of changes in land cover. Up to $43 \%$ of respondents were of the opinion that new ailments such as high blood pressure, cancer and diabetes had also emerged with onset of climate change, resulting in high cost of health care. Skin rash, toothaches, headaches and flu were other ailments mentioned as occurring due to climate-related changes.

\section{Human-wildlife conflicts resulting from land cover change}

Results showed that $87 \%$ of the households had experienced some form of human-wildlife conflict over the study duration. Of the households who reported to have experienced some form of human wildlife conflict, death or injury by

Table 12. Effect of changes in rainfall on land cover and socio-economic well being.

\begin{tabular}{cccccc}
\hline & Amala & Nyangores & Sand River & Talek & Total \\
\hline $\begin{array}{c}\text { Disappearance of some } \\
\text { vegetation species }\end{array}$ & $19(35.2 \%)$ & $18(33.3 \%)$ & $4(7.4 \%)$ & $13(20.1 \%)$ & 54 \\
$\begin{array}{c}\text { High frequency of rains } \\
\text { leading to floods }\end{array}$ & $13(52.0 \%)$ & $7(28.0 \%)$ & $1(4.0 \%)$ & $4(16.0 \%)$ & 25 \\
$\begin{array}{c}\text { Too little rains leading } \\
\text { to prolonged droughts }\end{array}$ & $29(39.7 \%)$ & $22(30.1 \%)$ & $7(9.6 \%)$ & $15(20.5 \%)$ & 73 \\
$\begin{array}{c}\text { Unpredictable rainfall patterns } \\
\text { Shift in rainfall seasons }\end{array}$ & $50(36.2 \%)$ & $57(41.3 \%)$ & $12(8.7 \%)$ & $19(13.8 \%)$ & 138 \\
Other indicators & $40(34.2 \%)$ & $53(45.3 \%)$ & $15(12.8 \%)$ & $19(16.2 \%)$ & 117 \\
Total & $1(100 \%)$ & $0(0.0 \%)$ & $0(0.0 \%)$ & $0(0.0 \%)$ & 1 \\
& $\mathbf{1 5 2}$ & $\mathbf{1 5 7}$ & $\mathbf{3 9}$ & $\mathbf{7 0}$ & $\mathbf{4 1 8}$ \\
\hline
\end{tabular}


wildlife and destruction of crops accounted for $58.11 \%$ and $40.54 \%$ of the responses, respectively. Insecurity within the community accounted for $50 \%$ of responses on the consequences of human-wildlife conflicts. Increased hospital bills for those injured and court fines resulting from killing of wildlife both accounted for 19\%, whereas reduced working hours during crop production accounted for $13 \%$ of the responses on consequences of human-wildlife conflicts (Figure 13).

Only $19.9 \%$ of respondents reported practicing wildlife co-management, compared to $70.8 \%$ who did not and $9.3 \%$ who did not respond to the question. With regard to effect of land cover change on wildlife, only $36.6 \%$ of the respondents responded, out of whom $12.9 \%$ reported that low wildlife population leads to reduction in tourism in the region, $10.5 \%$ reported reduced income from tourist activities while $10 \%$ reported reduced crop yields resulting from wildlife destruction of crop farms.

\section{Effect of land cover change on household income}

Monthly household income was dependent on the effects of changes in rainfall and temperature patterns on household's wellbeing $\left(\chi^{2}=35.531, \mathrm{P}=0.039\right)$. The results were also supported by the fact that fewer households that reported decrease of diseases earned between KES 10,000 and 30,000, with a z-score of -2.2 which was smaller than the critical value (-1.96) (Table 13).

\section{Focus Group Discussion Findings}

\section{Knowledge of the impact of climate on land cover}

Most FGD participants were aware of climate change and its impacts on the land cover having reported observing changes in climate in recent times. Participants noted that long ago, rainfall patterns were predictable, which is not the case currently. They lamented that this unpredictability has affected vegetation cover, crop and animal production which according to them had become more severe than in the past. Some of the changes mentioned included drying up of trees and other vegetation, increase in crop diseases and pests, increase in malaria cases which was not the case previously and "colored rainfall" attributed to

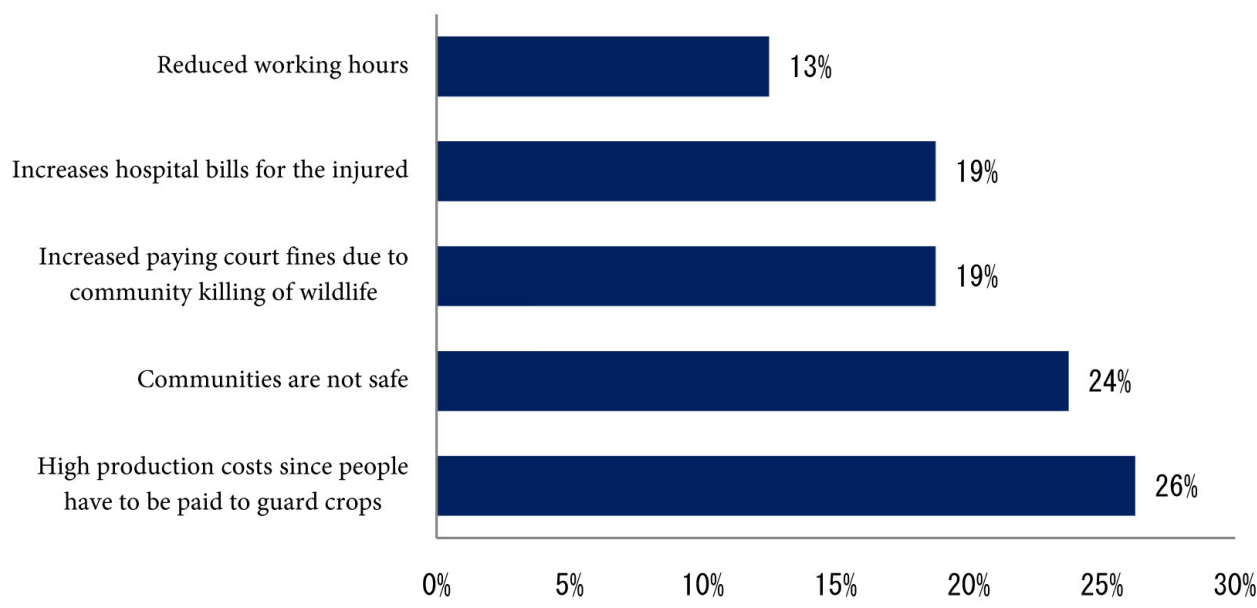

Figure 13. Consequences of human-wildlife conflict on human wellbeing. 
Table 13. Effects of land cover change on household income.

\begin{tabular}{|c|c|c|c|c|c|c|c|}
\hline Monthly HH Income & & $\begin{array}{l}\text { Decrease of } \\
\text { diseases }\end{array}$ & $\begin{array}{l}\text { Decreased yield } \\
\text { resulting in high } \\
\text { HH income }\end{array}$ & $\begin{array}{l}\text { Increase in diseases } \\
\text { resulting in high cost of } \\
\text { health care }\end{array}$ & $\begin{array}{l}\text { High yield } \\
\text { esulting in high } \\
\mathrm{HH} \text { income }\end{array}$ & $\begin{array}{l}\text { Increased cost of } \\
\text { water treatment }\end{array}$ & Total \\
\hline \multirow{4}{*}{ Other HH Income } & Count & 0 & 2 & 2 & 1 & 0 & 6 \\
\hline & Expected Count & 0.4 & 1 & 2.3 & 0.6 & 1.6 & 6 \\
\hline & Residual & -0.4 & 1 & -0.3 & 0.4 & -1.6 & \\
\hline & Std. Residual & -0.7 & 1.1 & -0.2 & 0.5 & -1.2 & \\
\hline \multirow{4}{*}{ Less than 10,000} & Count & 21 & 27 & 68 & 12 & 51 & 182 \\
\hline & Expected Count & 13.1 & 29.2 & 71 & 17.9 & 47 & 182 \\
\hline & Residual & 7.9 & -2.2 & -3 & -5.9 & 4 & \\
\hline & Std. Residual & 2.2 & -0.4 & -0.4 & -1.4 & 0.6 & \\
\hline \multirow{4}{*}{$10,000-30,000$} & Count & 4 & 30 & 58 & 20 & 41 & 157 \\
\hline & Expected Count & 11.3 & 25.2 & 61.2 & 15.4 & 40.6 & 157 \\
\hline & Residual & -7.3 & 4.8 & -3.2 & 4.6 & 0.4 & \\
\hline & Std. Residual & -2.2 & 1 & -0.4 & 1.2 & 0.1 & \\
\hline \multirow{4}{*}{$30,001-50,000$} & Count & 2 & 5 & 27 & 6 & 14 & 55 \\
\hline & Expected Count & 3.9 & 8.8 & 21.4 & 5.4 & 14.2 & 55 \\
\hline & Residual & -1.9 & -3.8 & 5.6 & 0.6 & -0.2 & \\
\hline & Std. Residual & -1 & -1.3 & 1.2 & 0.3 & -0.1 & \\
\hline \multirow{4}{*}{ More than 50,000} & Count & 3 & 3 & 8 & 2 & 2 & 18 \\
\hline & Expected Count & 1.3 & 2.9 & 7 & 1.8 & 4.7 & 18 \\
\hline & Residual & 1.7 & 0.1 & 1 & 0.2 & -2.7 & \\
\hline & Std. Residual & 1.5 & 0.1 & 0.4 & 0.2 & -1.2 & \\
\hline Total & Expected Count & 30 & 67 & 163 & 41 & 108 & 418 \\
\hline
\end{tabular}

increased pollutants in the atmosphere. The FGD participants also reported noticing a reduction in crop productivity; particularly maize and beans in their farms. Land cover change in the region was mainly attributed to deforestation of indigenous forests. Participants observed that wild fruits and most indigenous fruits that were abundant in the past had also disappeared due to climate change, with only man made forests dotting the region. Some of their views are captured in the following excerpts:

"There has been an increase in temperature with some months being eXtremely hot. We experience long cold months which initially happened only around July and these changes have resulted in alteration of the planting seasons" (FGD discussant-Nyangores sub-catchment).

"Maize planting used to take place in February so as to benefit from the heavy rains, while harvesting would occur in May. This pattern has now changed because the seasons have become increasingly erratic and unpredictable. The month of June used to be a celebration month for farmers and livestock keepers 
because of fattening of livestock due to sufficient rains but this is not the case anymore. The changes in climate started becoming evident around 30 years ago in this region." (FGD discussant-Amala sub-catchment).

Additional causes of land cover change as cited by the participants included soil erosion, which was attributed to increased construction of local roads. Soil fertility loss also came up strongly among the FGD discussants especially from Amala and Nyangores sub-catchments who felt that soil fertility had reduced considerably forcing them to use fertilizers and manure unlike in the past. The excerpts below capture some of their views:

"The use of fertilizer started about 15 years ago, prior to that, we just used to plant crops without any fertilizer or manure. Potatoes which used to grow well in this region do not grow anymore. Nowadays, farmers cannot plan because of the increased unpredictability of the weather patterns. Farming has now become like betting due to increased unpredictability of the rainy season" (FGD discussant-Amala sub-catchment).

"Vegetation has reduced significantly and as a result, livestock grazing has been extended into wild animal habitats. We have seen majority of people here encroaching into forests and bushes cutting them down and turning forests into human settlements, and this has increased erosion. Some tree species have become extinct-e.g. cedar, among others' (FGD discussant-Nyangores sub-catchment).

With regard to water resources, respondents reported that the main cause of water pollution was increased human activities such as bathing, washing, cleaning, and swimming along the river. Participants observed that rainfall patterns had changed significantly due to climate change. They reported that rainfall used to be uniform and predictable in the past, but had become increasingly unpredictable with the rainy season appearing to have been reduced to short rains only. In all the discussions, climate change was frequently mentioned, but its linkage with human activities was not well comprehended by the discussants. Only one lady appeared knowledgeable of the link between human activities and climate change, citing activities like burning of forests, burning of waste, deforestation, and emission of gases from green houses as contributing to climate change. On the contrary, some discussants were of the opinion that climate change was a result of supernatural forces, while one male discussant mentioned "God's punishment" as one of the causes.

Most participants did state clearly the real causes of climate change and were able to link the observed land cover change to various proximate factors. For instance, change in land cover was described as bare land due to drought, or drying of shrubs and trees due to prolonged dry season. The predominantly maize cultivators expressed concerns in particular about declining soil fertility, and also attacks by pests, plant diseases and parasitic weeds. The pastoralists expressed concerns on the impacts of land cover degradation to the quality of pasture and the value of livestock and their products, as exemplified in the following excerpt:

"In the past, two cows could provide a bucket of milk, but now, even 10 cows cannot fill a cup with milk, and yet, they [cows] eat grass in sufficient quantity" 
(Male discussant-Talek sub-catchment).

All focus group discussants were in agreement that rains have decreased in recent times. In addition, they noted that rainfall has become irregular while there have been changes in the onset of the rainy and dry seasons, the duration of these seasons, and the occurrence of intermittent dry spells. When the causes of the perceived changes in rainfall patterns were discussed, the causes were not directly attributed to a changing climate; although it was attributed to other climatic parameters, such as wind in some focus groups, and more typically, either in passing or explicitly, to divine intervention as exemplified in the following excerpts:

"Nowadays we leave it to God. You do what you can, without knowing what you will collect. It is God who decides" (Female discussant-Talek sub-catchment).

"With the hot weather of this year, minds are open to believe that the season will be good. But, only God knows" (Male discussant-Amala sub-catchment).

\section{Discussion}

This socio-economic survey conducted between July and August 2018 sought to establish the drivers of land cover change and resulting effect on socio-economic wellbeing. The study involved analysis of land cover change, a household survey and focus group discussions with select community members. Based on the study findings, the dominant life forms 30 years ago across the study area were forest cover, shrubs lands, and grass lands. However, the general changes observed after the 30 year period (1987-2017), imply a rapid reduction in forest cover, shrub land and natural grassland, and a corresponding increase in crop land, built-up areas and bare land within the study area. Consistent with the current study findings, change in land cover over time has also been reported in Nepal by Uddin et al. [41] and in the transboundary Gandaki River Basin of Central Himalayas by Rai et al. [42]. Both studies suggested that land use and land cover changes were largely driven by pressure for increased food production, human settlements, infrastructure development, and tourism activities among other anthropogenic activities coupled with the effect of a rapidly changing climate.

In the current study, respondents drawn from all the four sub-catchments (Talek, Sand River, Amala and Nyangores) confirmed that land cover had indeed changed and the change was likely triggered by a number of factors, among them climatic, human and biophysical forces. In the current study, human settlement patterns, policy shifts, household size, wild animal abundance and climate change were identified as key drivers of land cover change in the four sub-catchments. Indirect factors like population growth and density were also critical drivers of land cover change through the ever-growing need for more food production that can only be gotten from farming and livestock keeping activities.

Further analysis of the current study findings revealed that average tempera- 
ture had a positive but moderate correlation with built up area and extent of bare land percentages. This suggests that the higher the percentage of built up areas, the higher the average temperature. Just as was reported in the household survey that rainfall patterns had changed, analysis of climate and land cover data showed a negative correlation between average rainfall and bare land as well as built up areas. This has implication by proxy, indicating that as more forested areas area cleared, its impact is felt in the change of climate. These findings are consistent with those reported by Matata et al. [43] in semi-arid areas of Tanzania, Gwate et al. [44], Palmer et al. [45], Lei et al. [46] and Forkel et al. [47] in other parts of the globe.

Although the drivers of land cover change are numerous and could include human influences, biophysical drivers and natural processes, the most commonly mentioned by the respondents in the current study was the human influence. Common livelihood activities such as subsistence rain-fed farming, livestock keeping and pastoralism practiced by communities residing within the study area were singled out as key drivers of land cover change in the Mara River Basin of Kenya. Pressure to produce more food for the ever-rising population has seen expansion of crop lands into areas previously forested and those covered with grass lands especially within Amala and Nyangores sub-catchments, thus contributing to the largest percentage in land cover in the two sub-catchments over the 30 year study period.

The change detection analysis based on remotely sensed data showed that large acres of grassland, forest cover and shrubland got diminished at the expense of crop land and built-up areas between 1987 and 2017. While forest cover dominated large tracts of land within Amala and Nyangores sub-catchments in 1987, they had reduced significantly over the 30 year period having been replaced by crop lands and to some extent built-up areas. Encroachment of forests played a key role in the increased crop lands witnessed at the expense of forest cover in the two sub-catchments. Consistent with the current study findings, Badege [48] also concluded that expansion of mixed farming practices in the highlands of Ethiopia was among the driving force for vegetation cover loss and land degradation.

For the Talek and Sand River sub-catchments where pastoralism was the predominant household livelihood economic activity and a way of life for many households, livestock keeping was reported to be the main driver of land cover change. The fact that communities in Talek and Sand River take pride in the sizes of herds that they keep at the household level, has pushed the livestock population beyond the land's carrying capacity. The diminishing grasslands and drying up of water pans in the region are key pointers to livestock overstocking in Talek and Sand River sub-catchments.

Reid et al. [49] also reported that climate change, range land fragmentation and rangeland degradation, coupled with settlement schemes often interfere with pasture land creating resources and mobility constraints for pastoralists who are increasingly dependent on livestock mobility. As a result, shortage of 
water and pasture are becoming more common these days triggering farmer-herder conflicts in some areas and human-wildlife conflicts in other areas [50] [51].

Demand for trees and their products (fuel and construction wood) also encourage forest clearing which leaves soils bare exposing them to erosion. In the current study, it was also reported that deforestation and increased land fragmentation in the basin increased soil erosion affecting land cover as well as the volume of surface runoff and sediment transport into aquatic ecosystems. This consequently affects the level of water quality in the nearby rivers and their tributaries. Consistent with the current findings, Lambin et al. [7] and Geist et al. [52] concluded that land cover conversions due to demographic pressure are more serious particularly to aquatic ecosystems in tropical regions.

The land cover conditions of the Mara River sub-catchments have also been modified or significantly transformed by the rapidly increasing population pressure. Human population in the basins continues to grow at the expense of limited land resources forcing the inhabitants to encroach on surrounding forests in a bid to produce more food. Focus Group Discussion (FGD) also asserted that land holding per capita had declined due to the increasing population. This situation has created pressure on limited land for agricultural production. Consistent with the current study findings, the demand for land for agricultural activities and biomass as a source of fuel and construction materials to meet the rising demands for the ever increasing population has also been reported in many other regions across the world by Badege [48], Woldeamlak [53], and Hurni et al. [54]. This is clear evidence in favor of the Malthusian and Neo-Malthusian theoretical premise and the stand of political ecologist school of thought regarding population dynamics, land system change and resource degradation [52] [55] [56] [57].

Significant changes in land cover can modify regional climate and influence rainfall and temperature trends. In the current study, respondents especially those from Amala and Nyangores sub-catchments reported irregular and unpredictable rain fall patterns with shorter rainy seasons that start late and end early in recent times unlike was the case 30 years ago. Temperatures were also said to have increased considerably, affecting farming and livestock keeping activities through reduced pasture lands and drying up of water sources. Majority of the respondents in the current study claimed that changes in climatic factors had negatively affected the productivity of their farm lands, implying that agricultural output on the basin had significantly declined. True to their observation, the GLM results showed that over time, rainfall had a positive effect on all crops grown, while temperature had a negative effect on crops and other vegetation. The negative coefficient suggested that excess temperature was detrimental to land cover and to a larger extent, household income. Studies have shown that changes in climate affect animal production and human health directly through the principal weather factors: temperature, rainfall, humidity, solar radiation and airflow and indirectly through alteration of their nutritional environment and 
changes in the epidemiology and dynamics of human [58] and livestock disease pathogens, pests and vectors [59] [60].

From the foregoing, it is clear that long-term effects of climate change (in relation to temperature and rainfall) on crop production are larger than short-term effects, an indication that farmers need to adapt effectively to reduce long term effects of climate variability. The findings also showed that the coefficients associated with temperature were much larger than those for rainfall, thus temperature seemed to have a greater impact on crop production compared to rainfall. This implies that temperature is likely to be a significant factor for crop yields in the Kenyan Mara River sub-catchments in the future. The current study findings thus suggest that climate has a non-linear relationship with crops, which is consistent with the findings of Fezzi and Bateman [61].

Besides crop farming, communities in the study area were livestock keepers especially in Sand and Talek sub-catchments where pastoralism was the main source of livelihood. The Mara River sub-catchments communities (especially Talek and Sand River sub-catchments) are traditionally livestock keepers and most kept large herds of cattle as a sign of wealth and pride. The current study findings established that the livestock keepers including the nomads, pastoralists and sedentary communities in the four sub-catchments have always relied on natural pasture and vegetation for their livestock over the last 30 years ago. However, in recent times, climate variability and overstocking had reduced natural pasture and vegetation making it difficult to feed their livestock. Generally the respondents reported experiencing negative impacts of increased temperature on livestock production through disruption of grazing patterns particularly during hot days, drying up of water source, miscarriage especially among small livestock, premature births and even death of young kids and lambs during migrations.

Scientifically, warming is thought to alter heat exchange between animal and environment, and also affect feed intake, mortality, growth and reproduction [62]. In addition, distance to watering points was reported to increase with each drought event, hence increasing the distance that humans and livestock are forced to trek and in the process affecting their health and production. Livestock deaths during extreme droughts can reduce livestock numbers considerably and subsequently the household income. To avoid this, pastoralist communities often move from one area to another in search of pasture and water. Such nomadic movements were also evident in Talek and Sand River Sub-catchments in the current study. Nevertheless, competition for pasture and water with wildlife from the adjacent Maasai Mara National Reserve is increasingly becoming a source of human-wildlife conflicts.

While a large majority of respondents had noticed some changes in rainfall and temperature most respondents seemed unaware of the causes of climate change but alluded to reasons like drought, increase in sunshine, land degradation and people abandoning their culture hence being punished by God. This is 
an indication of low awareness levels about climate change phenomenon among community members. Surprisingly, study respondents in the current study were aware of the importance of conservation and protection of natural resources. Restoration of a section of the Nyangores sub-catchment following the Kenya government's restoration programme led to the re-establishment of forest cover in an area whose forest cover had almost been wiped out [63]. This is a classical proof that with the right policies and good will, restoration of destroyed forests is indeed possible.

\section{Conflicts of Interest}

The authors declare no conflicts of interest regarding the publication of this paper.

\section{References}

[1] Sun, X., He, J., Shi, Y.Q., Zhu, X.D. and Li, Y.F. (2012) Spatiotemporal Change in Land Use Patterns of Coupled Human-Environment System with an Integrated Monitoring Approach: A Case Study of Lianyungang, China. Ecological Complexity, 12, 23-33. https://doi.org/10.1016/j.ecocom.2012.09.002

[2] Bagarinao, R.T. (2008) Land Use Change and Its Implications on the Environment and People's Health: The Case of Mananga Watershed in Metro Cebu, Philippines. Asia Life Sciences, 2, 65-76.

[3] Minale, A.S. (2013) Retrospective Analysis of Land Cover and Use Dynamics in Gilgel Abbay Watershed by Using GIS and Remote Sensing Techniques, Northwestern Ethiopia. International Journal of Geosciences, 4, 1003-1008. https://doi.org/10.4236/ijg.2013.47093

[4] Deryng, D., Sacks, W.J., Barford, C.C. and Ramankutty, N. (2011) Simulating the Effects of Climate and Agricultural Management Practices on Global Crop Yield. Global Biogeochemical Cycles, 25, GB2006. https://doi.org/10.1029/2009GB003765

[5] Hsiang, S.M., Meng, K.C. and Cane, M.A. (2011) Civil Conflicts Are Associated with the Global Climate. Nature, 476, 438-441. https://doi.org/10.1038/nature10311

[6] Savenije, H.H.G. and Hall, M.J. (1993) Climate and Land Use: A Feedback Mechanism? In: Water and Environment, Key to Africa's Development, Proceedings of Delft Conference, International Institute for Infrastructural, Hydraulic and Environmental Engineering, Delft, 3-4 June 1993, 93-108.

[7] Lambin, E.F., Geist, H.J. and Lepers, E. (2003) Dynamics of Land Use and Land Cover Change in Tropical Regions. Annual Review of Environment and Resources, 28, 206-241. https://doi.org/10.1146/annurev.energy.28.050302.105459

[8] Goldewijk, K.K. (2010) Land Use Changes during the Past 300 Years. Land Use, Land Cover and Soil Sciences, 1, 1-8.

[9] Ramankutty, N., Evan, A.T., Monfreda, C. and Foley, J.A. (2008) Farming the Planet: 1. Geographic Distribution of Global Agricultural Lands in the Year 2000. Global Biogeochemical Cycles, 22, GB1003. https://doi.org/10.1029/2007GB002952

[10] Foley, J.A., DeFries, R., Asner, G.P., Barford, C., Bonan, G., Carpenter, S.R., et al. (2005) Global Consequences of Land Use. Science, 309, 570-574. https://doi.org/10.1126/science.1111772

[11] Lambin, E. and Geist, H. (2006) Land Use Land Cover Change Local Process and 
Global Impacts. Springer-Verlag, Berlin, Heidelberg, Germany, 128. https://doi.org/10.1007/3-540-32202-7

[12] FAO (2004) Carbon Sequestration in Drylands Soils. FAO, Rome, Italy.

[13] Carmona, A. and Nahuelhual, L. (2012) Combining Land Transitions and Trajectories in Assessing Forest Cover Change. Applied Geography, 32, 904-915. https://doi.org/10.1016/j.apgeog.2011.09.006

[14] Brown, A.E., Western, A.W., McMahon, T.A. and Zhang, L. (2013) Impact of Forest Cover Changes on Annual Streamflow and Flow Duration Curves. Journal of $\mathrm{Hy}$ drology, 483, 39-50. https://doi.org/10.1016/j.jhydrol.2012.12.031

[15] Jewitt, D., Goodman, P.S., Erasmus, B.F.N., O’Connor, T.G. and Witkowski, E.T.F. (2015) Systematic Land Cover Change in KwaZulu-Natal South Africa: Implications for Biodiversity. South African Journal of Science, 111, 2015-0019. https://doi.org/10.17159/sajs.2015/20150019

[16] UNCCD (2013) Economic Assessment of Desertification, Sustainable Land Management and Resilience of Arid, Semi-Arid and Dry Sub-Humid Areas. Global Risk Forum (GRF Davos), United Nations Convention to Combat Desertification (UNCCD), Germany.

[17] Deresa, F. and Legesse, T. (2015) Cause of Land Degradation and Its Impacts on Livelihoods of the Population in Toke Kutaye Woreda, Ethiopia. International Journal of Scientific and Research Publications, 5, 2250-3153.

[18] Maitima, J.M., Olson, J.M., Mugatha, S.M., Mugisha, S. and Mutie, I.T. (2010) Land Use Changes, Impacts and Options for Sustaining Productivity and Livelihoods in the Basin Of Lake Victoria. Journal of Sustainable Development in Africa, 12, 189-206.

[19] Kalaba, F.K., Chirwa, P.W., Syampungani, S. and Ajayi, O.C. (2010) Contribution of Agroforestry to Biodiversity and Livelihoods Improvement in Rural Communities of Southern African Regions. In: Tscharntke, T., Leuschner, C., Veldkamp, E., Faust, H., Guhardja, E. and Bidin, A., Eds., Tropical Rainforests and Agro Forests under Global Change, Springer, Berlin, 461-476. https://doi.org/10.1007/978-3-642-00493-3_22

[20] Belcher, B., Ruiz Perez, M. and Achdiawan, R. (2005) Global Patterns and Trends in the Use and Management of Commercial NTFPs: Implications for Livelihoods and Conservation. World Development, 33, 1435-1452. https://doi.org/10.1016/j.worlddev.2004.10.007

[21] Kashaigili, J.J. (2008) Impacts of Land-Use and Land-Cover Changes on Flow Regimes of the Usangu Wetland and the Great Ruaha River, Tanzania. Physics and Chemistry of the Earth, 33, 640-647. https://doi.org/10.1016/j.pce.2008.06.014

[22] Bruijnzeel, L.A. (1990) Hydrology of Moist Tropical Forests and Effects of Conversion: A State of Knowledge Review. UNESCO International Hydrological Programme, 224.

[23] Eisenberg, J.N., Desai, M.A., Levy, K., Bates, S.J., Liang, S., Naumoff, K. and Scott, J.C. (2007) Environmental Determinants of Infectious Disease: A Framework for Tracking Causal Links and Guiding Public Health Research. Environmental Health Perspectives, 115, 1216-1223. https://doi.org/10.1289/ehp.9806

[24] Myers, S.S. and Patz, J. (2009) Emerging Threats to Human Health from Global Environmental Change. Annual Review of Environment \& Resources, 34, 223-252. https://doi.org/10.1146/annurev.environ.033108.102650

[25] Lemon, S.M., Sparling, F.P., Hamburg, M.A., Relman, D.A., Choffnes, E.R. and 
Mack, A. (2008) Vector-Borne Diseases: Understanding the Environmental, Human Health, and Ecological Connections. National Academies Press, Washington DC.

[26] Tadei, W.P., Thatcher, B.D., Santos, J.M., Scarpassa, V.M., Rodrigues, I.B. and Rafael, M.S. (1998) Ecologic Observations on Anopheline Vectors of Malaria in the Brazilian Amazon. The American Journal of Tropical Medicine and Hygiene, 59, 325-335. https://doi.org/10.4269/ajtmh.1998.59.325

[27] Vittor, A.Y., Gilman, R.H., Tielsch, J., Glass, G., Shields, T., Lozano, W.S., Pinedo-Cancino, V. and Patz, J.A. (2006) The Effect of Deforestation on the Human-Biting Rate of Anopheles darlingi, the Primary Vector of Falciparum Malaria in the Peruvian Amazon. The American Journal of Tropical Medicine and Hygiene, 74, 3-11. https://doi.org/10.4269/ajtmh.2006.74.3

[28] Cohuet, A., Simard, F., Wondji, C.S., Antonio-Nkondjio, C., Awono-Ambene, P. and Fontenille, D. (2004) High Malaria Transmission Intensity due to Anopheles Funestus (Diptera: Culicidae) in a Village of Savannah-Forest Transition Area in Cameroon. Journal of Medical Entomology, 41, 901-905.

https://doi.org/10.1603/0022-2585-41.5.901

[29] Patz, J.A., Confalonieri, U.E., et al. (2005) Human Health: Ecosystem Regulation of Infectious Diseases. In: Hassan, R.M., Scholes, R. and Ash, N., Eds., Ecosystems and Human Well-Being: Current State and Trends, Island Press, Washington DC, 391-415.

[30] Desjeux, P. (2001) The Increase in Risk Factors for Leishmaniasis Worldwide. Transactions of the Royal Society of Tropical Medicine and Hygiene, 95, 239-243. https://doi.org/10.1016/S0035-9203(01)90223-8

[31] Olson, J.M., Butt, B., Atieno, F., Maitima, J., Smucker, T.A., Muchugu, E., Murimi, G. and Xu, H. (2004) Multi-Scale Analysis of Land Use and Management Changes on the Eastern Slopes of Mt Kenya. LUCID Project Working Paper 20. ILRI (International Livestock Research Institute), Nairobi, Kenya.

[32] LVBC (2015) The Mara River Natural Resources Management Plan.

[33] Homewood, K., Lambin, E.F., Coast, E., Kariuki, A., Kikula, I., Kivelia, J., Said, M., Serneels, S. and Thompson, M. (2001) Long-Term Changes in Serengeti-Mara Wildebeest and Land Cover: Pastoralism, Population, or Policies? Proceedings of the National Academy of Sciences of the United States of America, 98, 12544-12549. https://doi.org/10.1073/pnas.221053998

[34] Mati, B.M., Mutie, S., Home, P., Mtalo, F. and Gadain, H. (2005) Land Use Changes in the Transboundary Mara Basin: A Threat to Pristine Wildlife Sanctuaries in East Africa. The 8th International River Symposium, Brisbane, Australia, 6-9 September 2005.

[35] Mati, B.M., Mutie, S., Gadain, H., Home, P. and Mtalo, F. (2008) Impacts of Land-Use/Cover Change on the Hydrology of the Transboundary Mara River, Kenya/Tanzania. Lakes \& Reservoirs. Science, Policy and Management for Sustainable Use, 13, 169-177. https://doi.org/10.1111/j.1440-1770.2008.00367.x

[36] Hoffman, C.M. (2007) Geospatial Mapping and Analysis of Water Availability-Demand-Use within the Mara River Basin. Florida International University, Miami, FL.

[37] Mwangi, H.M., Julich, S., Patil, S.D., McDonald, M.A. and Feger, K.H. (2016) Modelling the Impact of Agroforestry on Hydrology of Mara River Basin in East Africa. Hydrological Processes, 30, 3139-3155. https://doi.org/10.1002/hyp.10852

[38] Peng, J., Wu, J., Yin, H., Li, Z., Chang, Q. and Mu, T. (2008) Rural Land Use Change during 1986-2002 in Lijiang, China Based in Remote Sensing and GIS Data. 
Sensors, 8, 8201-8223. https://doi.org/10.3390/s8128201

[39] Singh, A. (1989) Digital Change Detection Techniques Using Remotely Sensed Data. International Journal of Remote Sensing, 10, 989-1003. https://doi.org/10.1080/01431168908903939

[40] Hsieh, H. and Shannon, S.E. (2005) Three Approaches to Qualitative Content Analysis. Qualitative Health Research, 15, 1277-1288. https://doi.org/10.1177/1049732305276687

[41] Uddin, K., Chaudhary, S., Chettri, N., Kotru, R., Murthy, M. and Chaudhary, R.P. (2015) The Changing Land Cover and Fragmenting Forest on the Roof of the World: A Case Study in Nepal's Kailash Sacred Landscape. Landscape and Urban Planning, 141, 1-10. https://doi.org/10.1016/j.landurbplan.2015.04.003

[42] Rai, R., Zhang, Y., Paudel, B., Acharya, B. and Basnet, L. (2018) Land Use and Land Cover Dynamics and Assessing the Ecosystem Service Values in the Trans-Boundary Gandaki River Basin, Central Himalayas. Sustainability, 10, 3052. https://doi.org/10.3390/su10093052

[43] Matata, P., Bushesha, M. and Msindai, J. (2019) Assessing Rainfall and Temperature Changes in Semi-Arid Areas of Tanzania. American Journal of Climate Change, 8 , 173-189. https://doi.org/10.4236/ajcc.2019.82010

[44] Gwate, O., Mantel, S.K., Gibson, L.A., Munch, Z. and Palmer, A.R. (2018) Exploring Dynamics of Evapotranspiration in Selected Land Cover Classes in a Sub-Humid Grassland: A Case Study in Quaternary Catchment S50E, South Africa. Journal of Arid Environments, 157, 66-76. https://doi.org/10.1016/j.jaridenv.2018.05.011

[45] Palmer, A.R., Finca, A., Mantel, S.K., Gwate, O., M€unch, Z. and Gibson, L.A. (2017) Determining fPAR and Leaf Area Index of Several Land Cover Classes in the Pot River and Tsitsa River Catchments of the Eastern Cape, South Africa. African Journal of Range \& Forage Science, 34, 33-37. https://doi.org/10.2989/10220119.2017.1306582

[46] Lei, T., Pang, Z., Wang, X., Li, L., Fu, J., Kan, G., et al. (2016) Drought and Carbon Cycling of Grassland Ecosystems under Global Change: A Review. Water, 8, 460. https://doi.org/10.3390/w8100460

[47] Forkel, M., Carvalhais, N., Verbesselt, J., Mahecha, M.D., Neigh, C.S.R. and Reichstein, M. (2013) Trend Change Detection in NDVI Time Series: Effects of Inter-Annual Variability and Methodology. Remote Sensing, 5, 2113-2144. https://doi.org/10.3390/rs5052113

[48] Badege, B. (2001) Deforestation and Land Degradation in the Ethiopian Highlands: A Strategy for Physical Recovery. Northeast African Studies, 8, 7-25. https://doi.org/10.1353/nas.2005.0014

[49] Reid, R.S., Fernández-Giménez, M.E. and Galvin, K.A. (2014) Dynamics and Resilience of Rangelands and Pastoral Peoples around the Globe. Annual Review of Environment and Resources, 39, 217-242. https://doi.org/10.1146/annurev-environ-020713-163329

[50] Korf, B., Hagmann, T. and Emmenegger, R. (2015) Re-Spacing African Drylands: Territorialization, Sedentarization and Indigenous Commodification in the Ethiopian Pastoral Frontier. The Journal of Peasant Studies, 42, 881-901. https://doi.org/10.1080/03066150.2015.1006628

[51] Brottem, L.V. (2016) Environmental Change and Farmer-Herder Conflict in Agro-Pastoral West Africa. Human Ecology, 44, 547-563. https://doi.org/10.1007/s10745-016-9846-5

[52] Geist, H., McConnell, W., Lambin, E.F., Moran, E., Alves, D. and Rudel, T. (2006) 
Causes and Trajectories of Land-Use/Cover Change. In: Lambin, E.F. and Geist, H., Eds., Land-Use and Land-Cover Change: Local Processes and Global Impact, Springer, Berlin, 41-70. https://doi.org/10.1007/3-540-32202-7_3

[53] Woldeamlak, B. (2002) Land Cover Dynamics Since the 1950s in Chemoga Watershed, Blue Nile Basin, Ethiopia. Mountain Research and Development, 22, 263-269. https://doi.org/10.1659/0276-4741(2002)022[0263:LCDSTI]2.0.CO;2

[54] Hurni, H., Tato, K. and Zeleke, G. (2005) The Implications of Changes in Population, Land Use, and Land Management for Surface Runoff in the Upper Nile Basin Area of Ethiopia. Mountain Research and Development, 25, 147-154. https://doi.org/10.1659/0276-4741(2005)025[0147:TIOCIP]2.0.CO;2

[55] Malthus, T.R. (1798) An Essay on the Principle of Population as It Affects the Future Improvement of Society. Johnson, London.

[56] Panayotou, T. (2000) Population and Environment. CID Working Paper No. 54. Harvard University, Center for International Development, Cambridge, MA. http://www2.cid.harvard.edu/cidwp/054.pdf

[57] Andersson, E., Brogaard, S. and Olsson, L. (2011) The Political Ecology of Land Degradation. The Annual Review of Environment and Resources, 36, 295-319. https://doi.org/10.1146/annurev-environ-033110-092827

[58] Dida, G.O., Anyona, D.N., Abuom, P.O., Akoko, D., Adoka, S.O., Matano, A.S., Owuor, P.O. and Ouma, C. (2018) Spatial Distribution and Habitat Characterization of Mosquito Species during the Dry Season along the Mara River and Its Tributaries, in Kenya and Tanzania. Infectious Diseases of Poverty, 7, 2. https://doi.org/10.1186/s40249-017-0385-0

[59] Baylis, M. and Githeko, A.K. (2006) The Effects of Climate Change on Infectious Diseases of Animals. Report for the Foresight Project on Detection of Infectious Diseases, Department of Trade and Industry, UK Government, 35.

[60] Rowlinson, P. (2008) Adapting Livestock Production Systems to Climate change-Temperate Zones. Livestock and Global Change Conference Proceedings, Tunisia.

[61] Fezzi, C. and Bateman, I. (2015) The Impact of Climate Change on Agriculture: Nonlinear Effects and Aggregation Bias in Ricardian Models of Farmland Values. Journal of the Association of Environmental and Resource Economists, 2, 57-92. https://doi.org/10.1086/680257

[62] Thornton, P.K., Van de Steeg, J., Notenbaert, A. and Herrrero, M. (2009) The Impacts of Climate Change on Livestock and Livestock Systems in Developing Countries: A Review of What We Know and What We Need to Know. Agricultural Systems, 101, 113-127. https://doi.org/10.1016/j.agsy.2009.05.002

[63] GoK (2007) Kenya Vision 2030. Government of Kenya, Nairobi. 